2006

\title{
That Pernicious Pop-Up, the Prima Facie Case
}

Michael Hayes

University of Baltimore School of Law, mjhayes@ubalt.edu

Follow this and additional works at: http://scholarworks.law.ubalt.edu/all_fac

Part of the Civil Rights and Discrimination Commons, and the Labor and Employment Law Commons

\section{Recommended Citation}

That Pernicious Pop-Up, the Prima Facie Case, 39 Suffolk U. L. Rev. 343 (2006)

This Article is brought to you for free and open access by the Faculty Scholarship at ScholarWorks@University of Baltimore School of Law. It has been accepted for inclusion in All Faculty Scholarship by an authorized administrator of ScholarWorks@University of Baltimore School of Law. For more information, please contact snolan@ubalt.edu. 


\title{
SUFFOLK UNIVERSITY LAW REVIEW
}

\begin{tabular}{lll}
\hline \hline Volume XXXIX & 2006 & Number 2
\end{tabular}

\section{That Pernicious Pop-Up, the Prima Facie Case}

\author{
Michael J. Hayes ${ }^{\dagger}$
}

\section{INTRODUCTION}

Since 1973, all federal courts have used the three-stage analysis established in McDonnell Douglas Corp. v. Green ${ }^{1}$ to decide a vast majority of intentional employment discrimination cases. ${ }^{2}$ During the 1990s, an increasing number of commentators criticized the McDonnell Douglas test, particularly the first stage, the so-called "prima facie case." At the dawn of a new decade, in 2000, the Supreme Court reconsidered the McDonnell Douglas test for the first time in years in Reeves v. Sanderson Plumbing Products, Inc. ${ }^{4}$ How did the Court treat the prima facie case, given the strong criticisms that had been leveled against it for several years? The Reeves Court made the prima facie case more important than ever.

${ }^{\dagger}$ Associate Professor of Law, University of Baltimore School of Law; B.S. 1985, Cornell University; J.D. 1988, University of Virginia. I thank my former Employment Discrimination student, Amy Askew, whose perceptive questions put me on the path to writing this article. I am grateful to my research assistant, Amanda Cope, for all the outstanding work she has done on this project for more than a year. Finally, I thank the University of Baltimore for providing financial support.

1. 411 U.S. 792 (1973).

2. See id. at 802-05.

3. See, e.g., Denny Chin \& Jodi Golinsky, Moving Beyond McDonnell Douglas: A Simplified Method for Assessing Evidence in Discrimination Cases, 64 BROOK. L. REV. 659, 668-69 (1998); Deborah C. Malamud, The Last Minuet: Disparate Treatment After Hicks, 93 MiCH. L. REv. 2229, 2243-47, 2282-88, 2298-2300, 2318-19 (1995); Stephen W. Smith, Title VII's National Anthem: Is There a Prima Facie Case for the Prima Facie Case?, 12 LAB. LAW. 371, $372-78$ (1997) (explaining several criticisms of prima facie case); see also Fisher v. Vassar College, 114 F.3d 1332, 1336-37 (2d Cir. 1997) (discussing prima facie case and strongly indicating limited usefulness of prima facie evidence in deciding discrimination cases); William $\mathbf{R}$. Corbett, Of Babies, Bathwater and Throwing Out Proof Structures: It's Not Time to Jettison McDonnell Douglas, 2 EMP. RTs. \& EMP. POL'Y J. 361, 367 (1998) (acknowledging Professor Malamud "clearly correct about the shortcomings of the prima facie case"); Kenneth R. Davis, The Stumbling Three-Step. BurdenShifting Approach in Employment Discrimination Cases, 61 BROOK. L. REV. 703, 704-05 (1995) (summarizing criticisms of McDonnell Douglas approach).

4. 530 U.S. $133(2000)$. 
In Reeves, the Supreme Court held for the first time that the strength of the prima facie case should be one of the main factors that courts consider when, at the third stage of the McDonnell Douglas analysis, they decide whether the plaintiff presented sufficient evidence for a reasonable jury to find intentional discrimination. ${ }^{5}$ From 1983, when the Supreme Court decided United States Postal Service Board of Governors v. Aikens, ${ }^{6}$ until Reeves, the Court's position had been that after the employer produced evidence of a nondiscriminatory reason for firing or rejecting the plaintiff, the prima facie case was no longer relevant. ${ }^{7}$ In Reeves, the Court held that the prima facie case, along with the evidence regarding the employer's reason for its action, were factors that should be considered in deciding whether to dismiss the plaintiff's case. $^{8}$

The Reeves decision marked a significant enhancement in the role of the prima facie case. Originally, the prima facie case played a screening function: the plaintiff's proof of the prinia facie case factual elements (for example, that the plaintiff had applied for a position or met minimum qualifications for the job) served only to "eliminate[] the most common non-discriminatory reasons for the [employer's action]." The plaintiff's proof of the prima facie case also impelled the employer to assert its nondiscriminatory reason for its action. If the plaintiff proved a prima facie case, and the employer failed to rebut it with a nondiscriminatory reason, then the employer would lose. ${ }^{10}$ Once the plaintiff established a prima facie case, the analysis turned to the credibility of the employer's proffered reason for its action and to any evidence of discriminatory motive. ${ }^{11}$ Thus, the prima facie case would no longer be germane.

In Reeves, the Supreme Court apparently changed all that. The Court said that the relevance of the prima facie case does not end once the employer asserts its reason for its action. ${ }^{12}$ The Court also said that the issue regarding

5. Id. at 148 .

6. 460 U.S. 711 (1983).

7. See infra Part II.B (explaining limitations Aikens imposed on relevance of prima facie case in latter stages of McDonnell Douglas analysis).

8. Reeves, 530 U.S. at 148-49 (listing factors court may consider when deciding judgment as a matter of law motion).

9. Tex. Dep't of Cmty. Affairs v. Burdine, 450 U.S. 248, 254 (1981); see also infra Part III.A (discussing elements of prima case defined by the Supreme Court and by lower federal courts).

10. See Burdine, 450 U.S. at 254-55 (explaining defendant's burden following plaintiff's establishment of prima facie case). In order to carry its burden, the defendant must proffer evidence of a legitimate, nondiscriminatory reason for the employment action. Id; see also Wright v. Southland Corp., 187 F.3d 1287 , 1292 (11th Cir. 1999) (acknowledging prima facie case functions to compel employers to assert nondiscriminatory reasons for their actions).

11. See McDonnell Douglas Corp. v. Green, 411 U.S. 792, 804-05 (1973) (identifying evidence relevant to showing of employer pretext).

12. Reeves v. Sanderson Plumbing Prods., Inc., 530 U.S. 133, 148-49 (explaining ongoing relevance of strength of prima face case). 
the plaintiff's prima facie case was no longer limited to whether the plaintiff had proven it, but how strong (or weak) that proof was. ${ }^{13}$ Thus, a plaintiff who has proven the elements of her prima facie case in the first stage can no longer rest assured that she has done all that the court requires of her. At the third stage, the issue of the prima facie case returns, popping up like an ad on the Internet, and this time the plaintiff must convince the court that her prima facie case is not only sufficient, but also "strong."14

This article contends that it is a mistake to allow the prima facie case to play a significant role in the third stage of the McDonnell Douglas analysis. Additionally, this article explains how the Aikens decision offered crucial insight into the proper role of the prima facie case in adjudging discrimination claims, and correctly concluded that the prime facie case should not be considered after the employer has presented a reason for its challenged action. Finally, this article argues that the Reeves decision, by making "strength of the prima facie case" a factor to be considered at the final stage of the McDonnell Douglas analysis, threatens to give the traditional prima facie case far greater weight than is sensible or just. ${ }^{15}$

Fortunately, the Reeves decision did not expressly overrule Aikens, and there is a plausible interpretation of Reeves that would leave intact the limits Aikens imposed on consideration of the prime facie case. This article argues that in Reeves's list of factors to be considered on summary judgment, the term "prima facie case" should be interpreted to mean all the evidence the plaintiff has offered to prove discrimination, rather than the very different and much narrower set of facts that have traditionally been used to define the term "prima facie case."

This article first explains the role the prima facie case has played in discrimination cases, from its creation in McDonnell Douglas through the Supreme Court's decisions in Aikens and Reeves, up to the application of Reeves by lower courts in the past several years. ${ }^{16}$ Next, this article focuses on Reeve's identification of "strength of the prima facie case" as a factor to be considered on summary judgment, and discusses why it would be unwise and unworkable to interpret the words "prima facie case" in that factor as having the same meaning as the "prima facie case" proved in the first stage of the McDonnell Douglas framework. ${ }^{17}$ Finally, this article explains how and why courts should prevent the prima facie case from "popping up" again in the third stage of the McDonnell Douglas analysis, where it would distort and disrupt the court from conducting a fair and reasoned evaluation of whether a plaintiff's

\footnotetext{
13. Id.

14. Id.

15. Id.

16. See infra Part II (providing overview of McDonnell Douglas prima facie case jurisprudence).

17. See infra Part III (discussing meaning of prima facie case at different stages of analysis).
} 
discrimination claim should go to a jury. ${ }^{18}$

\section{The Role of the PRima Facie CaSe}

\section{A. The McDonnell Douglas Analysis}

For more than thirty years, courts have used the three-stage McDonnell Douglas analysis to evaluate most claims of intentional discrimination. ${ }^{19}$ In the first stage, the plaintiff must meet its "initial burden ... of establishing a prima facie case of racial [or other] discrimination," which the plaintiff can do by proving specified factual elements. ${ }^{20}$ If the plaintiff carries her prima facie burden, then at the second stage the burden shifts to the defendant (usually an employer) to produce evidence of a "legitimate, nondiscriminatory reason" for the adverse action taken against the plaintiff. ${ }^{21}$ Finally, at the third stage, the plaintiff has an opportunity to prove that the reason given by the employer at the second stage is a "pretext", and that the true reason for the employer's action is discrimination. ${ }^{22}$

The McDonnell Douglas three-stage structure is still the standard mode of analysis used by courts in deciding intentional discrimination cases, though that could be changing. Some courts and commentators have concluded that the Supreme Court overruled McDonnell Douglas in Desert Palace, Inc. v. Costa. ${ }^{23}$ In Costa, the Supreme Court addressed a split among the circuits regarding the level of evidence necessary to qualify for the so-called "mixed-motive" instruction established by Section 107 of the 1991 amendments to the Civil Rights Act of $1964 .^{24}$ The Costa court rejected the view of some lower courts that the plaintiff must present "direct evidence" of discrimination to qualify for the mixed-motive instruction, and held that "a plaintiff need only present sufficient evidence for a reasonable jury to conclude, by a preponderance of the evidence, that [a protected characteristic] was a motivating factor for any employment practice" to obtain the instruction. ${ }^{25}$

Although the Costa decision never mentions McDonnell Douglas, a few federal district courts have held that Costa overruled or dramatically undercut

18. See infra Part IV (suggesting way in which to interpret Reeves consistent with Aikens).

19. See Underwood v. Perry County Comm'n, 431 F.3d 788, 794-95 (11th Cir. 2005) (applying McDonnell Douglas framework to case decided in December 2005).

20. McDonnell Douglas Corp. v. Green, 411 U.S. 792, 802 (1973). The factual elements will vary depending on the particular circumstances alleged in a given case. $I d$. at $802 \mathrm{n} .13$.

21. Id. In McDonnell Douglas, the Court required the employer to "articulate" such a reason. Id. Later, in Burdine, the Court clarified that the employer's burden at the second stage was to produce admissible evidence of one or more legitimate, nondiscriminatory reasons for its action. See Tex. Dep't of Cmty. Affairs v. Burdine, 450 U.S. 248, 255 (1981).

22. McDonnell Douglas, 411 U.S. at 804-05.

23. 539 U.S. 90 (2003).

24. Id. at $92,95,98$.

25. Id. at 101 . 
the McDonnell Douglas analysis. These courts have reasoned that, under Costa, the Section 107 instruction should apply to all intentional discrimination cases, thus obviating the McDonnell Douglas analysis. ${ }^{26}$ Similarly, three commentators contend that Costa has, in effect, "killed" the McDonnell Douglas analysis. ${ }^{27}$

The post-mortems for McDonnell Douglas are premature. No circuit court has yet concluded that Costa overruled McDonnell Douglas, and already some have held that it did not. ${ }^{28}$ Meanwhile, as one set of commentators observed in declaring McDonnell Douglas to be "alive and well," most courts continue to apply the McDonnell Douglas analysis to intentional discrimination cases. ${ }^{29}$ Some courts have held that, after Costa, plaintiffs may choose whether to prove their cases by using the McDonnell Douglas framework or by "demonstrating" that a discriminatory reason more likely than not motivated the employer. ${ }^{30}$ In addition, Costa may not affect the application of the McDonnell Douglas analysis to claims of age discrimination. ${ }^{31}$ As noted, the Costa court based its decision on an interpretation of Section 107 of the Civil Rights Act of 1991, a statute that amended Title VII and the Americans with Disabilities Act but failed to amend or even mention the Age Discrimination in Employment Act $(\mathrm{ADEA}){ }^{32}$ Consequently, a majority of courts and commentators have

26. See, e.g., Veeder v. Cargill, Inc., No. 02-1711, 2003 U.S. Dist. LEXIS 23245, at*18 (D. Minn. Dec. 23, 2003); Griffith v. City of Des Moines, No. 01-10537, 2003 U.S. Dist. LEXIS 14365, at *36 (S.D. lowa July 3, 2003), aff'd 387 F.3d 733 (8th Cir. 2004); Dare v. Wal-Mart Stores, Inc., 267 F. Supp. 2d 987, 990-92 (D. Minn. 2003).

27. See Henry L. Chambers, Jr., The Effect of Eliminating Distinctions Among Title VII Disparate Treatment Cases, 57 SMU L. REv. 83, 95-96 (2004) [hereinafter Chambers, Effect]; William R. Corbett, McDonnell Douglas, 1973-2003: May You Rest in Peace?, 6 U. PA. J. LAB. \& EMP. L. 199, 212-14 (2003); Jeffrey A. Van Detta, "Le Roi Est Mort; Vive Le Roil": An Essay on the Quiet Demise of McDonnell Douglas and the Transformation of Every Title VII Case after Desert Palace, Inc. v. Costa into a "Mixed-Motives" Case, 52 DRAKE L. REV. 71, 72-73 (2003).

28. See Cooper v. Southern Co., 390 F.3d 695, 725 n.17 (1 1 th Cir. 2004); Griffith v. City of Des Moines, 387 F.3d 733, 735-36 (8th Cir. 2004). The Eighth Circuit's rejection of the proposition that Costa overruled McDonnell Douglas is especially significant because two of the federal district courts that had held otherwise, the District of Minnesota and the Southern District of lowa, are within the jurisdiction of the Eighth Circuit. See supra note 26.

29. See Christopher R. Hedican, Jason M. Hedican \& Mark P.A. Hudson, McDonnell Douglas: Alive and Well, 52 Drake L. Rev. 383, 413-14; Matthew R. Scott \& Russell D. Chapman, Much Ado About NothingWhy Desert Palace Neither Murdered McDonnell Douglas Nor Transformed All Employment Discrimination Cases to Mixed-Motive, 36 ST. MARY's L.J. 395, 396 (2005).

30. See, e.g., Rachid v. Jack in the Box, Inc., 376 F.3d 305, 312-13 (5th Cir. 2004); McGinest v. GTE Serv. Corp., 360 F.3d 1103,1122 (9th Cir. 2004); Rishel v. Nationwide Mut. Ins. Co., 297 F. Supp. 2d 854, 865 (M.D.N.C. 2003); Dunbar v. Pepsi-Cola Gen. Bottlers of Iowa, Inc., 285 F. Supp. 2d 1180, $1197-98$ (N.D. lowa 2003).

31. See Daniel K. Brough, Note \& Comment, Adams v. Florida Power Corp. and the Trend of Lowering an Employer's Burden of Proof to Rebut Age Discrimination Claims, 2003 B.Y.U. L. REv. 1097, 1113 \& n.87 (noting most courts have held McDonnell Douglas analysis applies to intentional age discrimination claims).

32. See Howard Eglit, The Age Discrimination in Employment Act, Title VII, and the Civil Rights Act of 1991: Three Acts and a Dog That Didn't Bark, 39 WAYNE L. REv. 1093, 1153-55 (1993) (excerpting text of Section 107 and noting it did not explicitly amend ADEA). 
concluded that Section 107 does not apply to age discrimination. ${ }^{33}$ Accordingly, in the near future at least, courts will continue to apply the McDonnell Douglas analysis to hundreds of intentional discrimination claims every year.

\section{B. The Effect of Aikens}

In Aikens, an African-American postal employee claimed that the U.S. Postal Service discriminated against him due to his race by refusing to promote him to higher positions in the Washington, D.C. Post Office where he had worked for decades. ${ }^{34}$ After a bench trial, the district court judge entered judgment for the defendant employer. ${ }^{35}$ The trial judge dismissed the plaintiff's claim, in part, because he failed to show he was "“as qualified or more qualified' than the people who were promoted," and thus did not prove his prima facie case. ${ }^{36}$ The D.C. Circuit held that the district court erred in requiring the plaintiff to make such a showing as part of his prima facie case. ${ }^{37}$ Before the Supreme Court, the plaintiff argued that he submitted sufficient evidence to prove a prima facie case, while the employer contended that he had not. $^{38}$

After summarizing the posture of the case and the parties' arguments, the Supreme Court declared, "[b]ecause this case was fully tried on the merits, it is surprising to find the parties and the Court of Appeals still addressing the question whether Aikens made out a prima facie case." ${ }^{, 39}$ The Court added that, by "framing the issue" in terms of the prima facie case, the parties and appeals court "unnecessarily evaded the ultimate question of discrimination vel non."

The Supreme Court next discussed the role of the prima facie case in the McDonnell Douglas analysis, explaining that "[b]y establishing a prima facie

33. See, e.g., Mereish v. Walker, 359 F.3d 330, 339-40 (4th Cir. 2004) (expressing doubts regarding Section 107's applicability to ADEA); Miller v. Cigna Corp., 47 F.3d 586, 598-99 \& n.10 (3rd Cir. 1995) (holding Section 107 inapplicable to ADEA); Michael C. Harper, ADEA Doctrinal Impediments to the Fulfilment of the Wirtz Report Agenda, 31 U. RiCH. L. REv. 757, 772-74 (1997) (noting circuit courts do not apply Section 107's mixed-motive analysis to ADEA claims); Eglit, supra note 32, at 1158-72 (evaluating legislative history regarding Section 107's impact on ADEA). But see Rachid, 376 F.3d at 312 (concluding Costa applies to ADEA). The Fifth Circuit reasoned that, because of the similarities in the language of Title VII and the ADEA, Costa is applicable to age discrimination. Rachid, 376 F.3d at 311 . As noted, however, the Rachid court explained that Costa did not overrule, but only "modified," the McDonnell Douglas analysis. See id. at 312-13.

34. U.S. Postal Serv. Bd. of Governors v. Aikens, 460 U.S. 711,712 (1983).

35. Id. at 713.

36. Id. (quoting Aikens v. U.S. Postal Serv. Bd. of Governors, 665 F.2d 1057, 1058-59 (D.C. Cir. 1981) (per curiam)).

37. Id.

38. Aikens, 460 U.S. at 713.

39. Id. at $713-14$.

40. Id. at 714 . 
case, the plaintiff ... creates a rebuttable "presumption"" of discrimination." The employer can rebut this presumption, the Court observed, by producing admissible evidence of a nondiscriminatory reason for its action. ${ }^{42}$ Once the employer produces evidence of such a reason, the sufficiency of the plaintiff's prima facie case is no longer at issue. ${ }^{43}$ At that point, the only pertinent issue is the "ultimate question" of discrimination:

when the defendant fails to persuade the district court to dismiss the action for lack of a prima facie case, and responds to the plaintiff's proof by offering evidence of the reason for the plaintiff's rejection, the fact finder must then decide whether the rejection was discriminatory within the meaning of Title VII. ${ }^{44}$

The Aikens court thus concluded that it becomes irrelevant whether the plaintiff proved his prima facie case once the employer produces evidence of a reason for its action. The Court reemphasized this conclusion succinctly in its holding: "[w]here the defendant has done everything that would be required of him if the plaintiff had properly made out a prima facie case, whether the plaintiff really did so is no longer relevant. ${ }^{, 45}$ The Court held that the district court erred in "focus[ing] on the question of prima facie case rather than directly on the question of discrimination., ${ }^{, 46}$ Finally, the Court remanded the case to the district court with instructions to move beyond the issue of the prima facie case and "decide on the basis of the evidence before it whether the Postal Service discriminated against Aikens.

The most common application of the Aikens rule, at least in published opinions, is probably at the appellate level, when circuit courts observe that for

41. Id.

42. U.S. Postal Serv. Bd. of Governors v. Aikens, 460 U.S. 711,714 (1983).

43. Id. at 715 .

44. Id. at $714-15$

45. Id. at 715 .

46. Aikens, 460 U.S. at 717.

47. Id. at 717. The Aikens court concluded that the district court erroneously required the plaintiff to submit direct evidence of discriminatory intent, in light of the Court's earlier holding that "“[the] $\mathrm{McDonnell}$ Douglas formula does not require direct proof of discrimination." See id. at $714 \mathrm{n.3}$ (quoting Int'l Bhd. Of Teamsters v. United States, 431 U.S. $325,358 \mathrm{n} .44$ (1977)). Thus, the only new law established in Aikens was that the question of whether the plaintiff proved his prima facie case was no longer relevant after the employer produced evidence of a nondiscriminatory reason for its challenged action.

The Supreme Court in Aikens originally intended to decide broader issues of discrimination law. Professor Deborah Malamud, through in-depth research in the papers of the late Justice Thurgood Marshall, discovered Aikens memoranda and draft opinions that discussed abandoning the McDonnell Douglas analysis for certain types of employer decisions. See Malamud, supra note 3, at 2249-53. When no approach to the broader issues was able to gain the support of a majority of Justices, then-Associate Justice Rehnquist circulated an "alternate draft." Id. at 2253. Justice Rehnquist's draft, which eventually became the Aikens majority decision, decided the case on the narrower ground that the "adequacy of the plaintiff's prima facie showing ... was no longer relevant in light of the procedural posture of the case." Id. 
purposes of review it is no longer relevant whether the plaintiff proved its prima facie case. ${ }^{48}$ Most discrimination cases, however, do not reach the appellate level. Consequently, the more pertinent issue for most litigants is the effect of Aikens at the trial court level. At that level, Aikens limits when and how the employer may ask the judge to determine whether the plaintiff has proved her prima facie case and to grant dismissal if the plaintiff has not. According to Aikens, the judge can consider the sufficiency of the prima facie case only before the employer produces evidence of a nondiscriminatory reason for the challenged action, because once the employer does so, the adequacy of the plaintiff's prima facie case becomes irrelevant. ${ }^{49}$

This rule impelled the defendant to challenge the prima facie case early in the litigation process, before the defendant had presented any evidence of its own. For almost twenty years after Aikens, a defendant in some jurisdictions could challenge the plaintiff's prima facie case very early in the litigation process through a motion to dismiss under Rule 12(b)(6) of the Federal Rules of Civil Procedure by contending that the plaintiff's complaint "fail[ed] to state a claim upon which relief can be granted." ${ }^{50}$ Until 2002, a number of circuit courts took the position that a plaintiff's discrimination claim could be dismissed if the plaintiff failed to allege in the complaint all the required elements of a prima facie case of discrimination. ${ }^{51}$ As a result, several employers successfully persuaded district court judges to dismiss discrimination claims, before the employers had produced any evidence of a reason for its action, on the ground that the complaints failed to allege a prima facie case of discrimination. ${ }^{52}$

The Supreme Court's 2002 decision in Swierkewicz v. Sorema N.A. ${ }^{53}$ made dismissal on these grounds no longer possible. The district court in Swierkewicz dismissed the plaintiff's claim because his complaint "had not adequately alleged a prima facie case." dismissal by "relying on its settled precedent, which requires a plaintiff in an employment discrimination complaint to allege facts constituting a prima facie

48. See Kovacevich v. Kent State Univ., 224 F.3d 806, 823-24 \& n.10 (6th Cir. 2000) (noting Aikens cited often in appellate review and listing several circuit court decisions in which court applied Aikens).

49. U.S. Postal Serv. Bd. of Govemors v. Aikens, 460 U.S. 711,715 (1983).

50. See FED. R. CIV. P. 12(b)(6); see also infra note 51 (collecting circuit court decisions in which courts affirmed Rule 12(b)(6) dismissals of employment discrimination claims).

51. See, e.g., Berry v. Sunrise Home Health Care, Inc., 21 Fed. Appx. 284, 284-85 (6th Cir. 2001); Brown v. Coach Stores, Inc., 163 F.3d 706, 709-10 (2d Cir. 1998); Pruitt v. Howard County Sheriff's Dept., No. 951193, 1996 U.S. App. LEXIS 1266, at * 8-9 (4th Cir. Jan. 31, 1996); Chambers v. Wynne Sch. Dist., 909 F.2d 1214, 1215 (8th Cir. 1990).

52. See Suarez v. Charlotte-Mecklenburg Schs., 123 F. Supp. 883, 889 (W.D.N.C. 2000); Williams v. Keezer, No. 87-72350, 1988 U.S. Dist. LEXIS 17930, at *9-10 (E.D. Mich. Feb. 1, 1988); see also supra note 51 (citing decisions in which appellate courts affirmed dismissals for failure to allege all prima facie case elements).

53. 534 U.S. 506 (2002).

54. Id. at 509 . 
case of discrimination under the framework" established in McDonnell Douglas. ${ }^{55}$ The Supreme Court overturned the Second Circuit's decision, holding that the "prima facie case under McDonnell Douglas... is an evidentiary standard, not a pleading requirement." explained that a court could not require a complaint in a discrimination case to plead the facts necessary to establish a prima facie case. ${ }^{57}$ Such a requirement, the Court stated, would violate Rule 8(a)(2) of the Federal Rules of Civil Procedure, "which provides that a complaint must include only 'a short and plain statement of the claim showing that the pleader is entitled to relief.","58 Under Rule 8(a)(2), a plaintiff's complaint can be required only to "give the defendant fair notice of what the plaintiff's claim is and the grounds upon which it rests." 59 The Court found that this "notice pleading" standard was "easily satisfie[d]" by the plaintiff's complaint in which he alleged he had been fired because of his national origin and his age. ${ }^{60}$

After Swierkewicz, an employer cannot attack a plaintiff's prima facie case based solely on the pleadings. Any argument that the plaintiff cannot prove a prima facie case of discrimination must refer to facts and evidence (or the absence of evidence) outside the pleadings. Consequently, a judge would be required to treat that argument as a motion for summary judgment rather than a motion to dismiss. ${ }^{61}$ With an employer's challenge to the prima facie case now occurring after the "pleadings" stage of the litigation process, such a challenge will now most likely occur after the court has required the employer to present its nondiscriminatory reasons for its challenged action.

Rule 26(a) of the Federal Rules of Civil Procedure represents one means through which the employer might be required to present any reason it will rely on to defend its challenged action. Since 1993, Rule 26(a) has required parties to make "initial disclosures" early in the litigation process. ${ }^{62}$ These disclosure must include the identity of each individual "likely to have discoverable information that the disclosing party may use to support its claims or defenses" and the subjects of that information, and copies of documents that the disclosing party "may use to support its claims or defenses," among other

55. $I d$.

56. Id. at 510 .

57. Swierkewicz, 534 U.S. at 512

58. Id. at 512 (quoting FED. R. CIV. P. 8(a)(2)).

59. Id. at 512 (quoting Conley v. Gibson, 355 U.S. 41,47 (1957)).

60. Id. at $513-14$.

61. See FED. R. CIV. P. 12(b)(6), (c). Both rules provide that "[i]f, on a motion for judgment on the pleadings, matters outside the pleadings are presented to and not excluded by the court, the motion shall be treated as one for summary judgment and disposed of as provided in Rule 56." Id; see also J.R. Kemper, Annotation, What, Other Than Affidavits, Constitutes "Matters Outside the Pleadings," Which May Convert Motion Under Federal Rule of Civil Procedure 12(b), (c) Into Motion for Summary Judgment, 2 A.L.R. FED. 1027 (2002) (collecting cases in which federal courts have converted Rule 12(b) or 12(c) motion to dismiss into Rule 56 motion for summary judgment).

62. FED. R. CIV. P. 26(a)(1). 
information. ${ }^{63}$ In most discrimination cases, the employer's main defense will be that it had a nondiscriminatory reason for its challenged action. Therefore, the employer's initial disclosures will usually include information and documents that identify the alleged reason for its action.

Even if the employer does not reveal its reason in its Rule 26(a) "initial disclosures", the plaintiff can require the employer to produce its reason and the evidence supporting it through discovery. If the employer moves for summary judgment prior to discovery, the plaintiff can rely on Rule 56(f) of the Federal Rules of Civil Procedure to ask the judge to deny or postpone the judgment until the plaintiff can gather additional evidence through discovery. ${ }^{64}$ In all likelihood, the judge will not consider the defendant employer's motion for summary judgment until after the plaintiff has had a reasonable opportunity to conduct discovery. ${ }^{65}$ Consequently, by the time a court considers an employer's motion for summary judgment, the court will have before it evidence of the employer's alleged reason for its action. ${ }^{66}$

Under these circumstances, one could interpret Aikens to preclude the employer from challenging the sufficiency of the plaintiff's prima facie case, because the prima facie case becomes "irrelevant" once the employer has produced evidence of a reason for its action. Some federal courts, however, construed Aikens in a way that permitted courts to grant summary judgment on two alternative bases. ${ }^{67}$ The court could grant summary judgment if the defendant demonstrated the plaintiff failed to establish a prima facie case. ${ }^{68}$ Alternatively, even if the plaintiff established a prima facie case, the court could grant summary judgment if the employer presented evidence of a nondiscriminatory reason for its action that the plaintiff could not genuinely dispute. $^{69}$ In Curry v. E-Systems, Inc., ${ }^{70}$ the Fourth Circuit explained this

63. See FED. R. CIV. P. 26(a)(1)(A), (B).

64. See FED. R. CIV. P. 56(f) (stating court "may refuse the application for judgment or may order a continuance to permit affidavits to be obtained or depositions to be taken or discovery to be had or may make such other order as is just").

65. See, e.g., Chernova v. Elec. Sys. Servs., Inc., 247 F. Supp. 2d 720, 722 (D. Md. 2003) (granting plaintiff continuance under Rule 56(f) to allow plaintiff to conduct discovery); see generally Jean F. Rydstrom, Annotation, Sufficiency of Showing, Under Rule 56() of Federal Rules of Civil Procedure, Of Inability to Present by Affidavit Facts Justifying Opposition to Motion for Summary Judgment, 47 A.L.R. FED. 206 (2004) (collecting Rule 56(f) cases). This collection makes clear that in discrimination and many other types of cases, summary judgment is usually not granted until after the plaintiff has had time and an opportunity to conduct discovery.

66. See Malamud, supra note 3, at 2269-71 (discussing avenues through which employer will produce evidence of alleged reasons for employment decision). The employer's "early pleadings," answers to interrogatories, requests for admissions, and pretrial memoranda, will reveal the alleged reason for its action. See id.

67. See Mitchell v. Data Gen. Corp., 12 F.3d 1310, 1316 (4th Cir. 1993) (summarizing "alternative" arguments employers can make in summary judgment motion).

68. Id.

69. Id.

70. No. 94-1779, 1995 U.S. App. LEXIS 34724 (4th Cir. Dec. 11, 1995) (per curiam). 
construction of Aikens, and illustrated the procedure that courts should use to comply with that decision. ${ }^{71}$

The Curry court held that

where an employer-defendant as movant has contended both that the claimant's submissions fail to establish a prima facie case or, alternatively, to present a genuine issue as to the credence of an asserted nondiscriminatory reason, our practice (at both levels) [trial and summary judgment] has been to address these in order as separate inquiries. ${ }^{72}$

In a footnote, the court explained how this approach could be squared with Aikens, essentially reasoning that at the summary judgment phase (as contrasted with trial) the sufficiency of the plaintiff's prima facie case could still be relevant, as long as that issue was decided before the court considered the employer's reason. ${ }^{73}$ Accordingly, the court ended the footnote by explaining, "the first logical inquiry is whether the plaintiffs' proffered evidence would make out a prima facie case, and hence survive a motion to dismiss, before ever getting to any possible 'pretext' issues." employer's challenge to a plaintiff's prima facie case could be considered on summary judgment as long as the court evaluated that issue separately from, and prior to, consideration of the employer's alleged reason for its action.

Only a mind reader could know whether judges followed the strictures of Aikens and duly limited their consideration of the plaintiff's prima facie case when considering summary judgment motions in discrimination cases. The Reeves decision, however, apparently rendered such restrictions moot.

\section{The Effect of Reeves}

The Supreme Court granted certiorari in Reeves to resolve a circuit court split regarding the correct standard for judgment as a matter of law or summary judgment in a discrimination case. ${ }^{75}$ The split concerned whether a plaintiff in a discrimination case could survive summary judgment, and reach a jury, if the only evidence she presented was a "prima facie case of discrimination (as

71. See id. at *7-11.

72. Id. at *8 (emphasis added).

73. See id. at $* 8 \mathrm{n}$.2.

74. Curry, 1995 U.S. App. LEXIS 34724 , at $* 8$ n.2.

75. See Reeves v. Sanderson Plumbing Prods., Inc., 530 U.S. 133, 137 (2000). In Reeves, the Court reviewed the district court's denial of the employer's motions for judgment as a matter of law, made during and after the trial under Rule 50 of the Federal Rules of Civil Procedure. See id. at 137, 138-39. The standards for granting judgment as a matter of law under Rule 50 and summary judgment under Rule 56 are essentially the same. See Anderson v. Liberty Lobby, Inc., 477 U.S. 242, 251-52 (1986). Consequently, lower courts have applied Reeves to rulings on summary judgment and judgment as a matter of law motions. See infra Part II.D (discussing lower court decisions applying Reeves). 
defined in McDonnell Douglas) combined with sufficient evidence for a reasonable factfinder to reject the employer's nondiscriminatory explanation for its decision ...."76 The Supreme Court held that such evidence could be sufficient for a plaintiff to avoid summary judgment because "a plaintiff's prima facie case, combined with sufficient evidence to find that the employer's asserted justification is false, may permit the trier of fact to conclude that the employer unlawfully discriminated." 77

The Supreme Court immediately added, however, that "[c]ertainly there will be instances where, although the plaintiff has established a prima facie case and set forth sufficient evidence to reject the defendant's explanation, no rational factfinder could conclude that the action was discriminatory." 78 To illustrate, the Court highlighted cases in which "the record conclusively revealed some other, nondiscriminatory reason for the employer's decision, or ... [in which] the plaintiff created only a weak issue of fact as to whether the employer's reason was untrue and there was abundant and uncontroverted independent evidence that no discrimination had occurred."79

In the next paragraph, the most important of the Reeves case, the Supreme Court clarified when summary judgment should be granted in a discrimination case. The Court explained, "[w] $w$ hether judgment as a matter of law is appropriate in any particular case will depend on a number of factors." ${ }^{\text {"80 }}$ The first factor that the Court listed was "the strength of the plaintiff's prima facie case." ${ }^{.11}$ The Court then added, as the other factors, "the probative value of the proof that the employer's explanation is false, and any other evidence that supports the employer's case and that properly may be considered on a motion for judgment as a matter of law., ${ }^{, 82}$

Later in its decision, the Court applied these factors and the summary judgment standard to Reeves's facts. ${ }^{83}$ The Court concluded that the plaintiff presented sufficient evidence to overcome a summary judgment motion and prevail at trial. ${ }^{84}$ In reaching its conclusion, the Court mentioned three times that the plaintiff had proved a prima facie case of discrimination but made no

76. Reeves, 530 U.S. at 140 (citations omitted). In the lower courts, Reeves has been applied far more often to rulings on summary judgment than to rulings in judgment as a matter of law. See infra Part II.D (presenting overview of post-Reeves jurisprudence). Therefore, this article will use the term "summary judgment" to refer to the procedure for determining whether a plaintiff has sufficient evidence to submit his or her discrimination case to the jury.

77. Id. at 148.

78. Id.

79. Reeves, 530 U.S. at 148.

80. Id.

81. Id. at $148-49$.

82. Id. at 149.

83. Reeves v. Sanderson Plumbing Prods., Inc., 520 U.S. 133, 151-54 (2000) (holding plaintiff offered sufficient evidence for jury to find employer intentionally discriminated).

84. Id. at 151-154. 
comment on the strength or weakness of that case. ${ }^{85}$ Additionally, the Court's decision relied upon plaintiff's evidence that the employer's reason was pretextual. $^{86}$ The Court did comment on the strength of the pretext evidence, stating that the plaintiff "made a substantial showing that respondent's explanation was false." $" 87$ Finally, the Court noted that the plaintiff presented "additional evidence of age-based animus," in particular, discriminatory remarks by an executive who played a key role in the decision to terminate the plaintiff. $^{88}$

In Reeves, the Court quoted Aikens three times but never discussed Aiken's rulings regarding the prima facie case. ${ }^{89}$ The Reeves court, however, without explicitly acknowledging it was doing so, removed the limits that Aikens placed on the relevance of the prima facie case. Aikens held that once the employer produced evidence of a reason for its action, the prima facie case was irrelevant. Later, lower courts decided that the prima facie case could be considered after the employer produced evidence of a reason. Still, courts held that the prima facie case should be considered separately from, and prior to, the evaluation of the employer's reason. In Reeves, the Supreme Court included the prima facie case and evidence regarding the employer's reason as factors courts should consider, together, in deciding whether summary judgment was appropriate. Moreover, after Reeves, courts may consider not only whether the plaintiff proved the prima facie elements, but also the strength of the plaintiff's prima facie case. Thus, pre-Reeves, if a court found that a plaintiff proved its prima facie case, it had no further reason to consider the elements of that case. Post-Reeves, courts are to take a "second look" at the evidence supporting the prima facie case, and can decide that such evidence is not "strong" enough for a plaintiff to avoid summary judgment. Lower courts have followed Reeves's guidance and considered the strength of a plaintiff's prima facie case in deciding whether to grant the defendant summary judgment.

85. See id. at 151-53.

86. Id. at 151-53.

87. Reeves, 530 U.S. at 144

88. Id. at 151-53.

89. Id. at $141,142,148$. First, the Reeves court quoted Aikens to substantiate its observations that " the question facing triers of fact in discrimination cases is both sensitive and difficult,' and that '[ $t$ ]here will seldom be 'eyewitness' testimony as to the employer's mental processes...." Reeves, 530 U.S. at 141 (alteration in original) (quoting U.S. Postal Serv. Bd. of Governors v. Aikens, 460 U.S. 711, 716). The second quotation highlighted that after the employer meets its burden of producing evidence of a non-discriminatory reason for its action, the "sole remaining issue [is] 'discrimination vel non." Reeves, 530 U.S. at 142 (quoting U.S. Postal Serv. Bd. of Governors v. Aikens, 460 U.S. 711, 714). Finally, Reeves referenced Aikens for the proposition that "trial courts should not "treat discrimination differently from other ultimate questions of fact." Reeves, 530 U.S. at 148 (quoting St. Mary's Honor Ctr. v. Hicks, 509 U.S. 502, 524 (1993) quoting U.S. Postal Serv. Bd. of Governors v. Aikens, 460 U.S. 711,716$)$ ). 


\section{Post-Reeves Decisions}

Three recent federal district court decisions illustrate how, under Reeves, the court can revisit the prima facie case and decide it is not strong enough to allow the plaintiff to go to trial even if the plaintiff proved the prima facie elements. ${ }^{90}$ Most recently, in Marron, a magistrate judge found in her report and recommendations that the plaintiff established a prima facie case of age discrimination. $^{91}$ The district court judge agreed and found that the plaintiff's prima facie case was "legally sufficient." ${ }^{, 92}$ The district court quoted Reeves and noted that the "strength of the plaintiff's prima facie case" was a relevant factor in deciding if the plaintiff's case should go to trial. ${ }^{93}$ Next, the court found that the plaintiff's prima facie case was "quite weak - indeed, the bare minimum required to carry a burden itself frequently described as "minimal.",94 Finally, the court found that the weakness of the plaintiff's prima facie case left him with nothing more than "quarrels with some of the explanations" given by the employer for its rejection of plaintiff, and this was insufficient for the plaintiff to survive summary judgment. ${ }^{95}$

Similarly, in Morris, after finding that "the plaintiff ... presented a prima facie case of age discrimination, albeit a weak one," the court quoted the Reeves factors, including the strength of the prima facie case. ${ }^{96}$ Applying those factors, the court declared the plaintiff's prima facie case and pretext evidence to be weak. Therefore, the court granted the defendant's summary judgment motion. ${ }^{97}$ In DeWeese, the court treated the plaintiff in the same fashion. Specifically, the court found that the plaintiff satisfied her prima facie burden but concluded that her "prima facie case [was] weak." 98 Based on the weakness of the plaintiff's prima facie case and the other Reeves factors, the court granted the defendant's summary judgment motion. ${ }^{99}$

In many other cases, federal trial court judges have applied the Reeves factors and relied on a weak prima facie case as a basis for dismissing the plaintiff's claim. For example, in Gaston v. Home Depot USA, Inc., ${ }^{100}$ a federal

90. See Marron v. N.Y. City Campaign Fin. Bd., No. 02-5562LAK, 2004 U.S. Dist. LEXIS 9122, at *5-6 (S.D.N.Y. May 21, 2004); Morris v. Charter One Bank, F.S.B., 275 F. Supp. 2d. 249, 257-60 (N.D.N.Y. 2003); DeWeese v. DaimlerChrysler Corp., 120 F. Supp. 2d 735, 751 (S.D. Ind. 2000).

91. Marron, 2004 U.S. Dist. LEXIS, at *1.

92. Id. at *5.

93. Id.

94. Id.

95. Marron, 2004 U.S. Dist. LEXIS, at *5-6.

96. Morris v. Charter One Bank, F.S.B, 275 F. Supp. 2d 249, 255-56 (S.D.N.Y. 2003); see also id. at 256 (stating "plaintiff has set forth a prima facie case"); id. at 257 (excerpting Reeves factors).

97. Morris, 275 F. Supp. 2 d at 260.

98. DeWeese v. DaimlerChrysler Corp., 120 F. Supp. 2d 735, 751 (S.D. Ind. 2000); see also id. at 748-49 (concluding presented sufficient evidence to meet her prima facie burden).

99. Id. at 751 .

100. 129 F. Supp. 2d 1355 (S.D. Fla. 2001). 
court in Florida declared the plaintiff's prima facie case "exceedingly weak." The Eleventh Circuit requires the plaintiff to show that she was treated "less favorably" than similarly situated employees. ${ }^{102}$ In Gaston, the persons the plaintiff presented as comparators were not sufficiently similar to the plaintiff. ${ }^{103}$ Therefore, the court held that, under Reeves, the plaintiff's prima facie case and evidence of pretext were not strong enough to avoid summary judgment. ${ }^{104}$ Gaston is just one example of dozens of federal district court decisions in which a court granted summary judgment based, at least in part, on the Reeves weak prima facie case factor. ${ }^{105}$

Circuit courts have also relied on the weak prima facie case factor in affirming grants of summary judgment. The Eighth Circuit, for example, in two age discrimination cases, applied the Reeves factors and held that the plaintiff's "weak" prima facie case supported granting summary judgment for the employer. ${ }^{106}$ In Dammen, the court assumed that the plaintiff proved the elements of his prima facie case, but immediately observed the weakness of the fourth prima facie element of his case. ${ }^{107}$ The fourth element required the plaintiff to show "that, after his discharge, 'the position remained open and the employer sought applicants with similar qualifications to fill the position.",108 The court concluded that the fourth element of Dammen's case was "weakened by uncontroverted evidence offered by UniMed that Dammen's position was eliminated upon his termination and re-created later in name only, as the new position included duties not held by Dammen prior to his dismissal." 109 The court relied on the weakness of this element in affirming summary judgment against Dammen. In particular, the court held that "[e]ven assuming Dammen has presented a prima facie case of age discrimination, the weakness of his prima facie case and the low probative value of his evidence that UniMed's explanation is false convinces us that he has failed to present a submissible case of age discrimination." 110

101. Id. at 1375 .

102. Id. at 1368 (citing, inter alia, Walker v. Mortham, 158 F.3d 1177, 1193 (11 th Cir. 1998)).

103. Id. at $1368-72$.

104. Gaston, 129 F. Supp. $2 \mathrm{~d}$ at $1375-76$.

105. See, e.g., McLeod v. Connecticut, No. 03-1397, 2004 U.S. Dist. LEXIS 21108 ,at *6-7 (D. Conn. Sept. 30, 2004); Diaz v. Weill Med. College, No. 02-7380, 2004 U.S. Dist. LEXIS 2054, at *52, 83-85 (S.D.N.Y. Feb. 13, 2004); Bumiche v. GE Automation Servs., Inc., 306 F. Supp. 2d 233, 238-40 (N.D.N.Y. 2004); Lester v. Natsios, 290 F. Supp. 2d 11, ?41-43 (D.D.C. 2003); Robinson v. N.Y. City Health Dep't, No. 00-8969, 2001 U.S. Dist. LEXIS 10810, at *26, 27 (S.D.N.Y. July 30, 2001), aff d, No. 04-1489, U.S. Dist. LEXIS 13286 (2d Cir. June 24, 2005); Sheets v. Nat'l Computer Sys., 2000 U.S. Dist. LEXIS 21657, at *25, 26 (S.D. Ia. Dec. 7 , 2000).

106. See Girten v. McRentals, Inc., 337 F.3d 979, 982 (8th Cir. 2003); Dammen v. UniMed Med. Ctr., 236 F.3d 978, 982 (8th Cir. 2001) (affirming summary judgment).

107. Dammen, 236 F.3d at 981.

108. Id. (quoting Bashara v. Black Hills Corp., 26 F.3d 820, 823 (8th Cir. 1994)).

109. Id.

110. Id. at 982 . 
The Eighth Circuit used a similar process in Girten. The court again assumed that the plaintiff established a prima facie case, but found that "the prima facie case [was] not particularly strong." 111 As in Dammen, the source of the weakness was the "replacement" element, as the court found that "[ $t]$ he nine year age difference between Mr. Girten and his replacement may not be sufficient to infer age discrimination."112 The court concluded that the plaintiffs failed to establish a strong prima facie case and presented virtually no evidence of pretext. ${ }^{13}$ Accordingly, the court held that no reasonable trier of fact could conclude that the defendant discriminated on the basis of age and affirmed summary judgment. ${ }^{114}$

The Second Circuit relied heavily on the weakness of the plaintiff's prima facie case in affirming summary judgment for the employer in Hutchinson $v$. Weiss, Peck \& Greer, L.L.C. ${ }^{115}$ The court held that, even assuming that the employer's stated reason for discharging the plaintiff was pretextual, the plaintiff failed the Reeves standard for avoiding summary judgment. ${ }^{116}$ The court reiterated the Reeves factors, beginning with "the strength of the prima facie case ..."."117 Next, the court found that "Hutchinson's prima facie case [was] extremely weak." 118 Largely on this basis, the Second Circuit concluded that "Hutchinson's prima facie case plus his proof that WPG's reason for his termination was pretextual does not provide evidence from which a reasonable jury" could find age discrimination. ${ }^{19}$

Similar to the Hutchinson court, the court in Wolde-Meskel v. Argus Community, Inc. ${ }^{120}$ found that, even assuming the plaintiff proved pretext, the plaintiff's claim should be dismissed because of a weak prima facie case. The Wolde-Meskel court stated that when the plaintiff establishes a weak prima facie case, the Reeves decision dictates that the plaintiff must offer more than evidence of pretext to avoid summary judgment. The court held, "even if Wolde-Meskel's defenses and explanations do create a genuine issue of fact [as to credibility of employer's reasons], since his prima facie case is-at bestweak, Reeves mandates that plaintiff come forward with evidence suggesting discrimination and not just the falsity of his employer's proffered reasons." 21 In other words, proof of the prima facie case plus evidence of pretext is not enough for a plaintiff to get to trial if the court adjudges the prima facie case to

111. Girten, 337 F.3d at 982 .

112. Id. (noting age differences render plaintiffs not similarly situated).

113. Id. at 983.

114. Id.

115. No. 00-7351, 2000 U.S. App. LEXIS 31863 (2d Cir. Dec. 13, 2000).

116. Id. at *7.

117. Id. (quoting Reeves v. Sanderson Plumbing Prods., Inc., 530 U.S. at 148-49).

118. Id.

119. Hutchinson, 2000 U.S. App. LEXIS 31863, at *7-8.

120. No. 99-10112, 2001 U.S. Dist. LEXIS 11261 (S.D.N.Y. Aug. 7, 2001)

121. Id. at *28. 
be "weak."

Courts do not always identify their bases for judgments. For example, in Selph v. Farmer Bros., Co. ${ }^{122}$, the Ninth Circuit, without explanation, held that the plaintiff's prima facie case was weak. Later, citing the Reeves factors, the court concluded, "[c]onsidering the strength of Selph's prima facie case, which was weak, the limited probative value of the proof that his employer's explanation was false, and other evidence that supports the employer's case, the district court correctly determined that Farmer Brothers was entitled to judgment as a matter of law."123 The Selph court did not explain which factors were most important to its conclusion that the employer was entitled to summary judgment.

A few courts have relied on a plaintiff's "strong" prima facie case as a basis for denying an employer's motion for summary judgment. For example, in EEOC v. Sears Roebuck \& Co., ${ }^{124}$ the Fourth Circuit noted, while discussing the prima facie stage of the analysis, that "the prima facie case here is a strong one." 125 The court later held that, under Reeves, this "strong prima facie case of national origin discrimination" along with "ample evidence to discredit" the employer's proffered reasons for rejecting the plaintiff, was sufficient to permit the trier of fact to infer discrimination, and therefore sufficient "to entitle a plaintiff to survive a motion for summary judgment."126 The Ninth Circuit, in Chuang v. University of California, ${ }^{127}$ held that "the evidence constituting [plaintiff's] prima facie case is sufficiently strong to raise a genuine issue of material fact regarding the truth of [employer's] proffered non-discriminatory reasons." 128 By tying the strength of the plaintiff's prima facie case evidence to the amount of evidence needed to create an issue of fact as to the employer's reason, the Chuang court applied almost a "sliding scale" approach in which a strong prima facie case could lessen the evidence of pretext required to get to trial. ${ }^{129}$ In other cases, courts have referred back to the plaintiff's prima facie case when discussing whether the employer's proffered reason for its action was pretextual. ${ }^{130}$ In these cases, however, the courts looked back not at the prima facie case per se, but at some of the evidence the plaintiff presented to

122. 56 Fed. Appx. 399 (9th Cir. 2003).

123. Id. at 400 .

124. 243 F.3d 846 (4th Cir. 2001).

125. Id. at 851 .

126. Id. at 854 .

127. 225 F.3d 1115 (9th Cir. 2000).

128. Chuang, 225 F.3d at 1127 . The court here particularly pointed to the plaintiff's "extraordinary qualifications." Id.

129. Compare $i d$. at $1127-28$ (holding plaintiff made sufficiently strong prima facie case to raise genuine issue of material fact regarding falsity of employer's reason), with Wolde-Meskel v. Argus Cmty., Inc., No. 9910112, 2001 U.S. Dist. LEXIS 11261, at *28 (S.D.N.Y. Aug. 7, 2001) (holding plaintiff must present additional evidence of discrimination, not just pretext, if prima facie case is weak).

130. See Laxton v. Gap, Inc., 333 F.3d 572, 582 (5th Cir. 2003). 
prove the prima facie case. The court considered such evidence (e.g., plaintiff's qualifications) because it related to the employer's reason for its action (e.g., the plaintiff was unqualified). ${ }^{131}$

\section{III. "STRENGTH OF The PRIMA Facie CaSe": What Does It MeAN?}

Federal circuit and district courts already apply the Supreme Court's ruling in Reeves that "the strength of the plaintiff's prima facie case" is one of the main factors courts should consider in deciding whether a discrimination plaintiff should survive a motion for summary judgment or judgment as a matter of law. To date, however, lower courts have not seriously examined the meaning of that factor. Consequently, many significant questions remain regarding the meaning behind the term "strength of the prime facie case."

On closer review, the meaning of the term "strength of the prime facie case" breaks down into a set of two sub-questions: (1) What is the meaning of the term "prima facie case?", and (2) what are the bases for judging that a prima facie case is "strong" or "weak"?

\section{A. Meaning of "Prima Facie Case"}

In Reeves, the Supreme Court stated that the phrase "prima facie case" had the same meaning as the definition the Court had established in McDonnell Douglas. ${ }^{132}$ Thus, McDonnell Douglas serves as the logical starting point for ascertaining the meaning of the term "prima facie case" in Reeves.

The Reeves opinion stated that page 802 of McDonnell Douglas "defined" prima facie case. On page 802 of McDonnell Douglas, the Supreme Court held:

The complainant in a Title VII trial must carry the initial burden under the statute of establishing a prima facie case of racial discrimination. This may be done by showing (i) that he belongs to a racial minority; (ii) that he applied and was qualified for a job for which the employer was seeking applicants; (iii) that, despite his qualifications, he was rejected; and (iv) that, after his rejection, the position remained open and the employer continued to seek applicants from persons of complainant's qualifications.

Thus, the McDonnell Douglas court defined "prima facie case" in terms of particular factual elements that the plaintiff must prove. Importantly,

131. Id. The distinction between the evidence supporting the prima facie case, and the prima facie case as an integrated factor whose overall "strength" or "weakness" of the court considers as a whole, is discussed more fully at infra notes 221-225 and accompanying text.

132. See Reeves v. Sanderson Plumbing Prods., Inc., 530 U.S. 133, 140 (2000) (citing McDonnell Douglas Corp. v. Green, 411 U.S. 792, 802 (1973)).

133. McDonnell Douglas, 411 U.S. at 802. 
McDonnell Douglas includes a footnote stating, "[t]he facts necessarily will vary in Title VII cases, and the specification above of the prima facie proof required from respondent is not necessarily applicable in every respect to differing factual situations." 134 In subsequent decisions, the Supreme Court has reaffirmed that courts must avoid "inflexib[ility]" when deciding whether a plaintiff has proven the elements required to establish a prima facie case. ${ }^{135}$

Nevertheless, most courts, including the Supreme Court, describe the prima facie case in terms of standard factual elements the plaintiff must prove. For example, in Reeves, the Supreme Court determined the plaintiff had proven a prima facie case by satisfying a checklist of elements:

It is undisputed that petitioner satisfied this [prima facie] burden here: (i) at the time he was fired, he was a member of the class protected by the ADEA ("individuals who are at least 40 years of age; (ii) he was otherwise qualified for the position of Hinge Room supervisor, (iii) he was discharged by respondent, and (iv) respondent successively hired three persons in their thirties to fill petitioner's position. ${ }^{136}$

The Reeves approach exemplifies the typical approach in intentional discrimination cases to defining the prima facie case. The Supreme Court consistently evaluates a plaintiff's prima facie case by listing standard factual elements that the plaintiff has or has not proven. ${ }^{137}$

Since McDonnell Douglas, lower federal courts have almost always defined the prima facie case in terms of standard factual elements that the plaintiff must

134. Id. at $802 \mathrm{n} .13$.

135. See, e.g., Swierkiewicz v. Sorema N.A., 534 U.S. 506, 512 (2002) (stating "[g]iven that the prima facie case operates as a flexible evidentiary standard, it should not be transposed into a rigid pleading standard for discrimination cases"); Tex. Dep't of Cmty. Affairs v. Burdine, 450 U.S. 248, 253 n.6 (1981) (acknowledging "[i]n McDonnell Douglas, we described an appropriate model for a prima facie case of racial discrimination... We added, however, that this standard is not inflexible ...."); Furnco Constr. Corp. v. Waters, 438 U.S. 567, 576-77 (1978) (cautioning courts to avoid inflexibility when applying McDonnell Douglas framework).

136. Reeves, 530 U.S. at 142 (citation omitted).

137. See, e.g., St. Mary's Honor Ctr. v. Hicks, 509 U.S. 502, 506 (1993) (holding respondent satisfied minimal requirements of prima facie case by proving that (1) he is black, (2) he was qualified for the position of shift commander, (3) he was demoted from that position and ultimately discharged, and (4) the position remained open and was ultimately filled by a white man); Patterson v. McLean Credit Union, 491 U.S. 164, 186-87 (1989) (requiring petitioner to "prove by a preponderance of the evidence that she applied for and was qualified for an available position, that she was rejected, and that after she was rejected respondent either continued to seek applicants for the position, or, as is alleged here, filled the position with a white employee"); Furnco Constr. Corp. v. Waters, 438 U.S. 567, 576 (1978) (concluding respondents carried initial prima facie burden "by proving they were members of a racial minority; they did everything within their power to apply for employment; Furnco has conceded that they were qualified in every respect for the jobs which were about to be open; they were not offered employment, although Smith later was; and the employer continued to seek persons of similar qualifications"). 
prove. ${ }^{138}$ In the years since Reeves, courts have continued to apply their circuit's standard elements in assessing whether a plaintiff has established a prima facie case of discrimination. In hiring cases, the First, ${ }^{139}$ Third, $^{140}$ Fifth, ${ }^{141}$ Eighth, ${ }^{142}$ Ninth, ${ }^{143}$ Tenth, ${ }^{144}$ and Eleventh ${ }^{145}$ Circuits require a plaintiff to prove the exact elements identified in McDonnell Douglas in order to establish her prima facie case. The other circuits require the first three elements, but vary on the fourth. The Seventh Circuit requires that the person hired instead of the plaintiff be outside the plaintiff's protected class or that the position remain vacant. ${ }^{146}$ The Sixth Circuit requires that the plaintiff show that she was treated differently than similarly situated persons outside her protected class. ${ }^{147}$ The Second and Fourth Circuits impose a more demanding fourth element and call for plaintiffs to demonstrate that their rejections occurred "under circumstances giving rise to an inference of discrimination."

In cases alleging discriminatory termination, all the circuits have adopted standard elements that a plaintiff must prove to make a prima facie showing, but there is considerable variation among the circuits regarding the specific required elements. All the circuits include in the standard elements that the plaintiff was in a protected class and was in fact terminated. Circuits differ regarding the "qualification" element. The Third, ${ }^{149}$ Fifth, ${ }^{150}$ Sixth, ${ }^{151}$ Ninth, ${ }^{152}$ Tenth, ${ }^{153}$ and Eleventh ${ }^{154}$ Circuits list as their second element that the plaintiff was "qualified" for her position. The Fourth, ${ }^{155}$ Seventh, ${ }^{156}$ and Eighth ${ }^{157}$

138. See Barbara lindemann \& Paul Grossman, Employment Discrimination Law 714-15, 847-52 (3d ed. 1996). The book identifies several cases that set forth and apply their circuits' standard elements for a prima facie case of hiring discrimination. See id. at 714-15. The book similarly explains the standard elements of a prima facie case of discriminatory termination. See id. at 847-52.

139. See Gu v. Boston Police Dep't, 312 F.3d 6, 11 (1st Cir. 2002).

140. See Dorsey v. Pittsburgh Assocs., 90 Fed. Appx. 636, 638 (3d Cir. 2004); Fuentes v. Perskie, 32 F.3d 759, 763 (3d Cir. 1994).

141. See Marks v. St. Landry Parish Sch. Bd., 75 Fed. Appx. 233, 234 (5th Cir. 2003) (per curiam).

142. See Kenney v. Swift Transp., Inc., 347 F.3d 1041, 1044-1045 (8th Cir. 2003).

143. See Raad v. Fairbanks N. Star Borough, 323 F.3d 1185, 1193 n.5 (9th Cir. 2002).

144. See Garcia v. Pueblo Country Club, 299 F.3d 1233, 1238 (10th Cir. 2002).

145. See EEOC v. Joe's Stone Crabs, Inc., 296 F.3d 1265, 1273 (11th Cir. 2002).

146. See Cooper v. Murphysboro Bd. of Educ., 6 Fed. Appx. 438, 440 (7th Cir. 2001). The "outside the protected class" requirement compels, for example, a female plaintiff to show the employer hired a male or a minority plaintiff to show that the employer hired a Caucasian.

147. See Miller v. Aladdin Temp-Rite, L.L.C., 72 Fed. Appx. 378, 380 (6th Cir. 2003).

148. See Williams v. R.H. Donnelley, Corp., 368 F.3d 123, 126 (2d Cir. 2004); Mackey v. Shalala, 360 F.3d 463, 468 (4th Cir. 2004).

149. See Goosby v. Johnson \& Johnson Med., Inc., 228 F.3d 313, 318 (3rd Cir. 2000).

150. See Wooten v. St. Francis Medical Ctr., 108 Fed. Appx. 888, 890 (5th Cir. 2004).

151. See Succarde v. Fed. Express Corp., 106 Fed. Appx. 335, 339 (6th Cir. 2004).

152. See Bodett v. Coxcom, Inc., 366 F.3d 736, 743 (9th Cir. 2004).

153. See Rivera v. City \& County of Denver, 365 F.3d 912, 920 (10th Cir. 2004).

154. See Cuddeback v. Fla. Bd. of Educ., 381 F.3d 1230, 1235 (11th Cir. 2004).

155. See Hill v. Lockheed Martin Logistics Mgmt., Inc., 354 F.3d 277, 285 (4th Cir. 2004).

156. See Davis v. Con-Way Transp. Cent. Express, Inc. 368 F.3d 776, 784 (7th Cir. 2004).

157. See Wheeler v. Aventis Pharm., 360 F.3d 853, 857 (8th Cir. 2004) 
Circuits require that the plaintiff show her performance was "meeting her employer's legitimate expectations" near the time of her termination. Similarly, the Second Circuit requires the plaintiff to show she was "performing satisfactorily." 158

Even greater variation exists regarding the final element in termination cases. The Tenth Circuit requires only that a plaintiff show that her job was not eliminated after her termination. ${ }^{159}$ The First Circuit calls on the plaintiff to demonstrate that the employer sought a replacement with roughly equivalent qualifications. $^{160}$ The Fourth ${ }^{161}$ and Eleventh ${ }^{162}$ Circuits require a terminated plaintiff to show she was replaced by someone outside the protected class. ${ }^{163}$ The Third ${ }^{164}$ and Seventh ${ }^{165}$ Circuits call on the plaintiff to show that similarly situated persons who were not members of the plaintiff's protected class were treated more favorably. The Second ${ }^{166}$ and Eighth ${ }^{167}$ Circuits require the plaintiff to prove the termination occurred under circumstances giving rise to an inference of discrimination. In the Fifth, Sixth and Ninth Circuits, the final element consists of different combinations of the aforementioned requirements adopted in other circuits. ${ }^{168}$

As these cases demonstrate, courts continue to define the plaintiff's prima facie case in terms of standard factual elements that the plaintiff must prove. At least one court and two scholars, however, have posited alternative conceptions of the meaning behind the Reeves "prima facie case" term. In the unpublished decision Carberry v. Monarch Marking Systems, Inc., ${ }^{169}$ the Sixth Circuit held that "[a] prima facie case of employment discrimination is weak in the Reeves sense when, notwithstanding the failure of the defendant's proffered

158. See Duncan v. N.Y. City Transit Auth., 45 Fed. Appx. 14, 15-16 (2d Cir. 2002).

159. See Rivera v. City \& County of Denver, 365 F.3d 912, 920 (10th Cir. 2004).

160. See Benoit v. Technical Mfg. Corp., 331 F.3d 166, 173 (1 st Cir. 2003).

161. See Hill v. Lockheed Martin Logistics Mgmt., Inc., 354 F.3d 277, 285 (4th Cir. 2004).

162. See Cuddeback v. Fla. Bd. of Educ., 381 F.3d 1230, 1235 (11 th Cir. 2004).

163. See O'Connor v. Consol. Coin Caterers Corp., 517 U.S. 308, 311-13 (1996) (modifying "replacement" element to suit ADEA context). In age discrimination cases, the "replacement" element must be modified because the U.S. Supreme Court has held that an age discrimination plaintiff is not required to prove that his or her replacement was under age forty. Id. Consequently, in age discrimination cases, the Fourth and Eleventh Circuit's require a plaintiff to prove her replacement was outside the protected class or "significantly younger" than the plaintiff. See Smith v. United Refrigeration, Inc., 47 Fed. Appx. 674, 675 (4th Cir. 2002); Chapman v. AI Transp., 229 F.3d 1012, 1024 (11th Cir. 2000).

164. See Goosby v. Johnson \& Johnson Med., Inc., 228 F.3d 313, 319 (3rd Cir. 2000).

165. See Davis v. Con-Way Transp. Cent. Express, Inc., 368 F.3d 776, 784 (7th Cir. 2004).

166. See Duncan v. N.Y. City Transit Auth., 45 Fed. Appx. 14, 16 (2d Cir. 2002).

167. See Wheeler v. Aventis Pharm., 360 F.3d 853, 857 (8th Cir. 2004).

168. The Fifth and Sixth Circuits require that the plaintiff show either that she replaced by someone outside the protected class or that she was treated less favorably than a person outside the protected class. See Wooten v. St. Francis Medical Crr., 108 Fed. Appx. 888, 890 (5th Cir. 2004); Succarde v. Fed. Express Corp., 106 Fed. Appx. 335, 339 (6th Cir. 2004). The Ninth requires that the plaintiff show that similarly situated individuals outside the protected class were treated more favorably, or that other circumstances surrounding the termination give rise to an inference of discrimination. See Bodett v. Coxcom, Inc., 366 F.3d 736, 743 (9th Cir. 2004).

169. 30 Fed. Appx. 389 (6th Cir. 2002). 
explanation, "the record conclusively reveals some other, nondiscriminatory reason for the employer's decision....",170 In an article discussing Reeves, Professor Michael Zimmer suggested that Justice O'Connor's majority opinion "may . . . be using the term 'prima facie case' in the more general sense of the ultimate burden the plaintiff has to prove that she was a victim of defendant's discrimination."

Professor Henry Chambers discussed the possibility of a broader meaning of "prima facie case" in an article published one year after Reeves. ${ }^{172}$ Professor Chambers argued for a broader definition of prima facie case than the "checklist of facts" definition typically applied. He explained that " $[t]$ he prima facie case can be constructed in at least two ways - as a checklist of facts that appear relevant to discrimination or as a set of facts aimed directly at supporting an inference of discrimination." "173 Professor Chambers acknowledged that "the McDonnell Douglas Court's listing of specific facts that would suffice to prove a prima facie case in that factual setting might lead one to view the prima facie case as a checklist." 174 Still, he maintained that "the appropriate way to view the prima facie case is as a set of facts that creates an inference of discrimination."175 According to Professor Chambers, the term "prima facie case" should be understood to mean "any set of facts sufficient to support an inference of discrimination." 176

In Reeves and earlier Supreme Court discrimination decisions, there is support for either the argument that "prima facie case" means a "checklist" of standard elements, or the argument that it has the broader meaning of all the facts supporting the plaintiff's claim of discrimination. The Reeves court's statement that it meant the prima facie case "as defined in McDonnell Douglas," and its citation of the particular page of the McDonnell Douglas opinion on which the Court set forth the list of standard elements of a prima facie case of hiring discrimination support the checklist definition. ${ }^{177}$ In addition, the Court evaluated the standard elements of a prima facie case of discriminatory discharge to reach its conclusion that Reeves proved a prima

170. Id. at 394 (emphasis in original) (quoting Reeves v. Sanderson Plumbing Prods., Inc., 530 U.S. 133 , $148(2000))$.

171. Michael Zimmer, Leading By Example: An Holistic Approach to Individual Disparate Treatment Law, 11 KAN. J.L. \& PUB. POL'Y 177, 186 n.49 (2001) [hereinafter Zimmer, Leading].

172. See Henry Chambers, Discrimination, Plain and Simple, 36 TULSA L.J. 557, 566-67 (2001) [hereinafter Chambers, Discrimination].

173. Id.

174. Id. at 567

175. Id. Professor Chambers added, "[i]ndeed, that has been a vision attributed to the McDonnell Douglas test." Id. at 567.

176. Chambers, Discrimination, supra note 172, at 559. See also id. at 567 ("Courts viewing the prima facie case as any set of facts that supports an inference of discrimination have taken various paths to guarantee that the prima facie case does support an inference of discrimination.").

177. See Reeves v. Sanderson Plumbing Prods., Inc., 530 U.S. 133, 140 (2000). 
facie case. ${ }^{178}$ Moreover, Reeves lists the "strength of the prima facie case" factor separately from "the probative value of the proof that the employer's explanation is false" factor. ${ }^{179}$ If "prima facie case" meant all the evidence supporting an inference of discrimination, then the identification of evidence of pretext as a factor would be redundant. Finally, the Court in Reeves specifically found that evidence of the employer's false explanation is a "form of circumstantial evidence" that supports an inference of discrimination. ${ }^{180}$

In Burdine, a case on which the Reeves court repeatedly relied, the Supreme Court considered-and rejected-the position that the McDonnell Douglas "prima facie case" meant all evidence supporting an inference of discrimination. ${ }^{181}$ The Burdine court explained,

[t]he phrase "prima facie case" not only may denote the establishment of a legally mandatory, rebuttable presumption, but also may be used by courts to describe the plaintiff's burden of producing enough evidence to permit the trier of fact to infer the fact at issue. McDonnell Douglas should have made it apparent that in the Title VII context we use "prima facie case" in the former sense. $^{182}$

The "latter sense," which the Court rejected, more closely resembles the meaning of "prima facie case" suggested by Professors Zimmer and Chambers. Thus, if "prima facie case" in Reeves means all evidence supporting the plaintiff's case, then the meaning of the term has changed, at least to some degree, since Burdine.

Alternatively, there are also grounds for finding that the term "prima facie case," as used in Reeves, has a broad meaning. In the Reeves list of summary judgment factors, if "plaintiff's prima facie case" does not mean all evidence supporting the plaintiff's claim, then there is an imbalance in that standard to the detriment of plaintiffs. The other factors in the list are "the probative value of the proof that the employer's explanation is false, and any other evidence that supports the employer's case ...."183 The obvious counterbalance to the last factor would be "any evidence that supports the plaintiff's case," yet that is not mentioned. If the Supreme Court had intended to exclude some of the plaintiff's evidence from consideration on summary judgment, while allowing and even requiring consideration of all of the employer's evidence, then one would expect the Court to explain this disparity. Instead, the Court failed to

178. See id. at 142

179. See id. at $148-49$.

180. Id. at $147-48$.

181. See Tex. Dep't of Cmty. Affairs v. Burdine, 450 U.S. 248, 252.56 (1981); see also Reeves, 530 U.S. at 142-43 (citing and quoting Burdine).

182. Burdine, 450 U.S. at $254 \mathrm{n} .7$ (citation omitted).

183. Reeves v. Sanderson Plumbing Prods., Inc., 530 U.S. 133, 149 (2000). 
address the disparity. Perhaps the term "prima facie case" meant all the evidence supporting the plaintiff's claim, and thus no disparity actually existed.

Courts should not interpret "prima facie case" to mean "checklist of facts" because such an interpretation conflicts with the Aikens decision. ${ }^{184}$ Additionally, basing a summary judgment determination on the strength or weakness of the standard elements of a plaintiff's prima facie case is neither logical nor workable for most discrimination cases.

\section{B. Meaning of "Strong" (or "Weak") Prima Facie Case}

If the prima facie case is defined as a checklist of factual elements, then it will be extremely difficult, if not impossible, for courts to develop consistent or sensible standards for judging whether a prima facie case is "weak" or "strong." One major reason for this difficulty is that in the decades since McDonnell Douglas, courts have adopted numerous exceptions to and variations on the elements a plaintiff must prove to establish a prima facie case. For each exception or variation, courts will now have to decide. what effect it has on the "strength" of the plaintiff's prima facie case.

In McDonnell Douglas, the Supreme Court required the plaintiff to show that he applied for and was qualified for a position for which the employer was seeking applicants. ${ }^{185}$ Lower courts have adopted exceptions to both the "applied" and "qualified" elements. Courts have held that if an employer did not publicize a vacancy, then the plaintiff is not required to show that he or she applied for the position. ${ }^{186}$ Moreover, courts have announced that a plaintiff's "failure to formally apply for a job opening will not bar a Title VII plaintiff from establishing a prima facie claim of discriminatory hiring, as long as the plaintiff made every reasonable attempt to convey his interest in the job to the employer." 187

Several courts have similarly decided that, under some circumstances, a plaintiff can establish a prima facie case even if she fails to meet the stated qualifications for a job. In Carter v. Three Springs Residential Treatment, ${ }^{188}$ the Eleventh Circuit reversed a district court grant of summary judgment to the employer. ${ }^{189}$ The district court had determined that the plaintiff's prima facie case failed because he lacked a "clinical experience" requirement that the

184. See infra Part IV (discussing potential conflict between Reeves and Aikens decisions if courts adopt "checklist" definition of prima facie case).

185. McDonnell Douglas Corp. v. Green, 411 U.S. 792, 802 (1973).

186. See, e.g., Williams v. Giant Food, Inc., 370 F.3d 423, 431 (4th Cir. 2004); Mauro v. S. New England Telecomms., Inc., 208 F.3d 384, 387 (2d Cir. 2000); Carmichael v. Birmingham Saw Works, 738 F.2d 1126, 1133-34 (11th Cir. 1984).

187. EEOC v. Metal Serv. Co., 892 F.2d 341, 348 (3d Cir. 1990). Metal Serv. Co. cites several failure to promote and failure to hire cases in which the deciding court adopted an exception to the "applied" element. Id.

188. 132 F.3d 635 (11 th Cir. 1998).

189. Id. at 637. 
employer stated for the job. ${ }^{190}$ In reversing the district court, the Eleventh Circuit highlighted that the eventual hiree also failed the requirement. ${ }^{191}$ In a promotion case, the Eleventh Circuit found that the district court had erred in holding that the plaintiff's failure of an employer-required test meant that plaintiff failed the prima facie case, because other employees had been promoted without passing the test. ${ }^{192}$ The Fifth Circuit has contended that these and other cases establish that plaintiffs do not have to prove they met a job's stated qualifications if plaintiffs show that the persons hired also failed to meet the qualifications. ${ }^{193}$

Plaintiffs who fail the "application" and "qualification" elements have been able to rely on these and other exceptions to avoid dismissal of their case on the grounds of failure to prove a prima facie case. After Reeves, however, proof of the prima facie case is not the end of the matter, because the court must also consider the prima facie case's relative strength. Reeves makes relevant the question, do these judicially created exceptions affect the strength of the plaintiff's prima facie case? Put another way, are cases in which the plaintiff can prove the standard elements of a prima facie case "stronger" than those in which the plaintiff must rely on a judicially-created exception to one of those elements? There may not be a single answer to that question. Courts could decide that failure to satisfy the "application" element does not weaken the plaintiff's prima facie case, while failure to meet a stated qualification does.

With some standard elements of a prima facie case, the question becomes even more complicated. Many circuits demand that a termination, hiring, or promotion discrimination plaintiff show that the individual hired into the relevant position is outside the protected class. ${ }^{194}$ Courts have also created exceptions to this element. These exceptions require one to again consider whether reliance on an exception weakens the plaintiff's prima facie case. One relevant exception permits a plaintiff to satisfy her prima facie case, even if her replacement is of the same sex, race, national origin, etc., if she presents evidence the employer hired a replacement with the same characteristics as plaintiff to "cover up" discrimination. ${ }^{195}$ A forceful argument can be made that the presence of this sort of "cover up" evidence actually strengthens the plaintiff's discrimination claim. Thus, should courts recognize that plaintiffs

190. Id. at 643 .

191. Id.

192. See Sledge v. Goodyear Dunlop Tires N. Am., Ltd., 275 F.3d 1014, 1015-18 (11 th Cir. 2001).

193. See Johnson v. Louisiana, 351 F.3d 616, 623-25 (5th Cir. 2003).

194. See supra notes 161-165 and accompanying text (identifying circuits requiring, as an element, replacement by individual outside plaintiff's protected class). See generally Marla Swartz, Note, The Replacement Dilemma: An Argument for Eliminating a Non-Class Replacement Requirement in the Prima Facie Stage of Title VII Individual Disparate Treatment Discrimination Claims, 101 MiCH. L. REV. 1338 (2003).

195. See Brown v. McLean, 159 F.3d 898, 905-06 (4th Cir. 1998); Jones v. Western Geophysical Co., 669 F.2d 280, 284-85 (5th Cir. 1982). 
who fail the standard replacement element, but show they may fall within the "cover up" exception, have "stronger" prima facie cases than plaintiffs who meet the standard replacement element?

The replacement element generates an even more difficult question in age discrimination cases. The Supreme Court established, in $O^{\prime}$ Connor, that an age discrimination claimant is not required to prove that he or she was replaced by someone outside the protected class, that is, under the age of $40 .{ }^{196} O^{\prime}$ Connor also held, however, that age discrimination could not be proven when the plaintiff was replaced by an employee who was "insignificantly younger."197 Since $O^{\prime}$ Connor, lower courts have struggled to define what constitutes a "significant" age difference between the plaintiff and the replacement. ${ }^{198}$ The Reeves standard now adds another layer of complication to an already confusing situation. After Reeves, even if a court finds a "significant" age difference, the court must also ask whether that difference indicates a "weak" or "strong" prima facie case. Even for significant age differences, courts may eventually establish yet another distinction by differentiating between "significant but weak" and "significant and strong." If courts adopt this distinction, age discrimination cases would become more complex and difficult for plaintiffs to prove.

Certain courts have not only created exceptions to the standard elements of the prima facie case, but also established alternative elements to apply in certain situations. ${ }^{199}$ Courts will now have to decide how to apply the Reeves standard in cases involving such alternate elements. One controversial example is the "reverse discrimination" case. Courts have established that plaintiffs who cannot prove the standard "protected class" element of a prima facie case, such as Caucasian males, can nonetheless make a prima facie case of discrimination by proving an alternative element. ${ }^{200}$ For example, such plaintiffs may present evidence of "background circumstances" that suggest that "the defendant is the unusual employer who discriminates against the majority." 201 The application of the "protected class" element in cases of alleged reverse discrimination has produced conflicting decisions by courts, ${ }^{202}$ and due to the highly charged

196. O'Connor v. Consol. Coin Caterers Corp., 517 U.S. 308, 311-12 (1996).

197. Id. at 312-13.

198. See Grosjean v. First Energy Corp., 349 F.3d 332, 336-40 (6th Cir. 2003) (summarizing variety of judicial definitions of "significant" age difference); see generally Kurt Schaub, The "Substantially Younger" Requirement in O'Connor v. Consolidated Coin Caterers Corp.: Will ADEA Plaintiffs Lose Again?, 16 HOFSTRA LAB. \& EMP. L.J. 225 (1998) (criticizing "significant age difference" requirement).

199. See, e.g., Duke v. Uniroyal, Inc., 928 F.2d 1413, 1417-18 (4th Cir. 1991) (discussing alternatives to usual prima facie elements when case involves a reduction-in-force); Moore v. City of Charlotte, 754 F.2d $1100,1105-06$ (4th Cir. 1985) (identifying variations on the prima facie elements in cases of disciplinary decisions); Parker v. Baltimore \& Ohio R.R. Co., 652 F.2d 1012, 1017 (D.C. Cir. 1981) (explaining alternative to "plaintiff is in a protected class" element).

200. Parker, 652 F.2d at 1017.

201. See id.

202. See generally Brenda D. DiLuigi, Note, The Notari Alternative: A Better Approach to the Square- 
nature of reverse discrimination, intense public controversy. ${ }^{203}$ The Reeves standard will likely pour fuel on these flames. Courts must now decide whether a prima facie case of reverse discrimination is relatively strong, because it requires more evidence from a plaintiff than a standard case, or relatively weak, because an alternative element can never be as probative as the traditional "protected class" element. Either course would be strongly criticized, and disagreement and uncertainty will likely emerge on this issue.

Even in cases where no variations or exceptions apply, and the plaintiff proves the traditional elements of a prima facie case, the Reeves standard generates difficult questions. For each prima facie element, courts will have to determine the quantum of evidence sufficient to support a "strong" prima facie case. This will not always be a straightforward matter of, the more evidence the better. Take, for example, the element of qualification in hiring and promotion cases. In some decisions, courts have held that when a plaintiff has qualifications that far exceed those minimally required for the position that supports finding a "strong" prima facie case under the Reeves standard. ${ }^{204}$ By contrast, other courts have held that qualifications exceeding the requirements for the position make the plaintiff "overqualified" and weaken or negate the plaintiff's prima facie case. ${ }^{205}$

In sum, courts will confront a myriad of difficult and troubling questions as they try to define the meaning of "strength of the prima facie case" under the Reeves standard, especially if "prima facie case" is defined as a "checklist of facts" as in McDonnell Douglas. More importantly, courts have virtually no guidance in addressing these questions or in defining "strong" or "weak" prima facie case. The Reeves court failed to explain the meaning of this factor and did not apply it to the facts of the case. Although courts similarly lack guidance regarding the other two Reeves factors-"the probative value of the proof that the employer's explanation is false, and any other evidence that supports the employer's case" - their meaning is more readily understood, if not self-evident. ${ }^{206}$ Whether evidence indicates the falsity of an employer's

Peg-Round-Hole Problem Found in Reverse Discrimination Cases, 64 BRooK. L. REV. 353 (1998) (discussing conflict among courts regarding definition of elements of prima facie reverse discrimination case).

203. See generally e. christi cunningham, The Rise of Identity Politics I: The Myth of the Protected Class in Title VII Disparate Treatment Cases, 30 CONN. L. REv. 441 (1998); Timothy K. Giordano, Comment, Different Treatment for Non-Minority Plaintiffs under Title VII: A Call for Modification of the Background Circumstances Test to Ensure that Separate is Equal, 49 EMORY L.J. 993 (2000); Darren D. McClain, Comment, Racial Discrimination against the Majority in Hiring Practices: Courts' Misguided Attempts to Make Race-Conscious Law Color Blind, 30 StetSON L. REV. 755 (2000); Susan C. Thies, Comment, Mills v. Health Care Service Corporation: Are "Background Circumstances" Too Much to Ask of a Plaintiff Alleging Reverse Discrimination in Employment?, 74 ST. JOHN'S L. REV. 537 (2000) (illustrating the range of public opinion on reverse discrimination).

204. See EEOC v. Sears Roebuck \& Co., 243 F.3d 846, 851-52 (4th Cir. 2001).

205. See Rodgers v. Smithkline Beecham Corp., No. 93-4073, 1994 U.S. Dist. LEXIS 4582, at *11 (E.D. Pa. April 12, 1994).

206. Reeves v. Sanderson Plumbing Prods., Inc., 530 U.S. 133, 149 (2000). 
reason or discriminatory motive will either be obvious or determinable by widely accepted principles of logic or common sense. By contrast, the only limit on a court's judgment of whether a prima facie case is "strong" or "weak" is that court's own sense of what those terms mean. With so many unresolved issues regarding the definition of "strength of the prima facie case" and so little direction on how courts should address those issues, the judicial resolutions of those questions will likely be widely divergent and frequently arbitrary, and hence confusing and unfair. Therefore, it would be advisable for courts to adopt a new interpretation of Reeves, in which the term "prima facie case" is understood to mean something other than the checklist of factual elements set forth in McDonnell Douglas.

\section{PreVenting The PoP-UP: ReCONCILING AIKENS AND REEVES BY LIMITING THE ROLE OF THE PRIMA FACIE CASE}

If the term "prima facie case" has the same meaning in the Supreme Court's decisions in Aikens and Reeves, then those two decisions conflict. Aikens held that once the employer produced evidence of a reason for its action, the plaintiff's prima facie case is no longer relevant and should not be considered by the court. ${ }^{207}$ Conversely, Reeves lists "strength of the prima facie case" as one of the factors courts should consider even after the employer has produced evidence of a reason (indeed, along with the evidence regarding the employer's reason) when ruling on motions for summary judgment or judgment as a matter of a law.

Some courts have interpreted Aikens in a narrow way that avoids the conflict with Reeves. These courts held that Aikens makes the prima facie case irrelevant only after the case is "fully tried on the merits."208 In one particularly striking case, Teneyck $v$. Omni Shoreham Hotel, ${ }^{209}$ the D.C. Circuit affirmed the district court's dismissal of a hiring discrimination case because the plaintiff failed to prove that the employer had continued to hire applicants for the same position, a prima facie element. ${ }^{210}$ The court dismissed the claim despite witness testimony that such hiring had occurred. ${ }^{211}$ The D.C. Circuit distinguished the case from Aikens on the ground that "[Teneyck] was not "fully tried on the merits.",212 In at least two decisions, Judge Donald Nugent of the

207. U.S. Postal Serv. Bd. of Govemors v. Aikens, 460 U.S. 711,715 (1983).

208. Russell v. McKinney Hosp. Venture, Inc., 235 F.3d 219, 224 (5th Cir. 2000); see also Cardenas v. AT\&T Corp., 245 F.3d 994, 998-99 (8th Cir. 2001).

209. 365 F.3d 1139 (D.C. Cir. 2004).

210. Id. at 1154 .

211. Id.

212. Id. (quoting Aikens, 460 U.S. at 714). The D.C. Circuit acknowledged that the "District Court's decision to admit [the employer witnesses'] testimony to the record while simultaneously excluding it from consideration created a situation that normally should be avoided." Id. Despite this acknowledgement, the D.C. Circuit upheld the district court's decision because it allowed the employer witness's testimony to deal with the "logistical difficulty" of the future unavailability of that witness, and the plaintiff failed to object to the 
United States District Court for the Northern District of Ohio adopted an even narrower construction of Aikens. He held that Aikens restricted only what courts could do after a bench trial, and even then only when the court had denied a defendant's motion for directed verdict. ${ }^{213}$ In Petrone and Campbell, he stated, "Aikens... concluded that the district court could not revisit whether or not the plaintiffs had proven a prima facie case in a bench trial after previously concluding, at the close of the plaintiffs' case in chief, that the prima facie case had been made."214

The Sixth Circuit, in Kovacevich, correctly overruled Judge Nugent's line of cases. The Kovacevich court based its decision on a more careful reading of Aikens. The Sixth Circuit explained, "[b]oth its holding and language demonstrate that Aikens is not a narrow case, as the district court assumes... Aikens was not limited to bench trials following a judge's rejection of a directed verdict motion, as the district court has suggested elsewhere." 215 The court acknowledged that Aikens involved a bench trial and a district court's denial of the defendant's motion for directed verdict, but pointed out that "the Court made no effort to narrow its discussion to that procedural circumstance." 216 Instead, the Sixth Circuit observed, "when discussing the role of the prima facie case, the Aikens Court spoke broadly, stating unconditionally that district judges should not revisit a prima facie case once a defendant has presented evidence of its nondiscriminatory reason and the case has been tried on the merits."217

The Kovacevich court correctly described Aikens as a broad decision. ${ }^{218}$ Its statement that Aikens held that the prima facie case should not be revisited after the employer produced its reason and "the case has been tried on the merits", however, interpreted Aikens too narrowly. Kovacevich focused on the Supreme Court's statement in Aikens that "[b]ecause this case was fully tried on the merits, it is surprising to find the parties and the Court of Appeals still addressing the question whether Aikens made out a prima facie case." 219 The

procedure. Id.

213. See Petrone v. Cleveland State Univ., 993 F. Supp. 1119, 1130 (N.D. Ohio 1998); Coleman v. Toys "R" Us, Inc., 976 F. Supp. 713, 719 (N.D. Ohio 1997).

214. Petrone, 993 F. Supp. at 1130 ; Campbell, 976 F. Supp. at 719.

215. Kovacevich v. Kent State Univ., 224 F.3d 806, 823 (6th Cir. 2000) (citing Petrone, 993 F. Supp. at $1130)$.

216. Id.

217. Id. (citing U.S. Postal Serv. Bd. of Govemors v. Aikens, 460 U.S. 711, 714 (1983)).

218. See Kovacevich, 224 F.3d at 823 (acknowledging broad and unconditional instructions Aikens provides to district court judges regarding consideration of prima facie case).

219. U.S. Postal Serv. Bd. of Govemors v. Aikens, 460 U.S. 711, 713-14 (1983), quoted in Kovacevich, 224 F.3d at 824 . In his concurring opinion in Kovacevich, Judge Ronald Lee Gilman contended that the majority's rationale was "rooted in the Supreme Court's observation in Aikens that "following final judgment for the defendant in a Title VII case after a bench trial, it was 'surprising to find the parties and the Court of Appeals still addressing the question whether [the] plaintiff made out a prima facie case." Kovacevich, 224 F.3d at 836 (J. Gilman, concurring) (citation omitted) (quoting Aikens, 460 U.S. at 713-14). 
more important declaration in Aikens, however, was the holding that "[w]here the defendant has done everything that would be required of him if the plaintiff had properly made out a prima facie case, whether the plaintiff really did so is no longer relevant. Aikens thus held that the plaintiff's prima facie case becomes irrelevant once the employer has produced evidence of a nondiscriminatory reason for its action, which usually occurs long before a full trial is completed.

In Aikens, the Supreme Court offered crucial insight into the role of the prima facie case in the McDonnell Douglas analysis. The Court recognized that the prima facie case had no relevance once the employer produced evidence of a nondiscriminatory reason for its action. Prior to the employer's production of a reason, as the Supreme Court stated in Burdine, "[ $\mathrm{t}]$ he prima facie case serves an important function in the litigation: it eliminates the most common nondiscriminatory reasons for the [employer's action]. ${ }^{, 20}$ If the employer produces evidence of its reasons for its action against the plaintiff, then the employer also admits that no other reasons-common or notmotivated its action. Therefore, all other reasons, including those captured by the elements of the prima facie case, cannot possibly be relevant.

In Reeves, the prima facie case is not only treated as relevant, but also given weight equal to evidence that the employer's reason is false. If, in Reeves, the term "prima facie case" means the standard prima facie elements, then that would render the employer's asserted reason no more important than the "prima facie element" reasons, which the employer does not claim influenced its decision. That simply makes no sense.

The Kovacevich decision, in which the Sixth Circuit recognized the breadth of Aikens, offers a more sensible construction of Reeves. The Sixth Circuit explained, "[o]f course, evidence that bears upon elements of the prima facie case can also come into play in assessing the ultimate question of discrimination." 221 The court then cited Reeves to support that proposition and noted parenthetically that Reeves "[took] into account the evidence supporting the plaintiff's prima facie case as part of its consideration of the 'ultimate question' of intentional discrimination."222 The Kovacevich decision is certainly correct that some of the evidence a plaintiff would present to prove her prima facie case would also be relevant to other issues in a discrimination case. To prove their prima facie case, plaintiffs must offer evidence on issues such as their qualifications or the level of their on-the-job performance. These issues often relate directly to the reasons employers give for rejecting or firing plaintiffs.

If an employer's stated reason for not hiring or promoting a plaintiff is that

220. Burdine, 450 U.S. at 253-54.

221. Kovacevich v. Kent State Univ., 224 F.3d 806, 827 (6th Cir. 2000) (emphasis added).

222. Id. (quoting Reeves v. Sanderson Plumbing Prods., Inc., 530 U.S. 133, 152-53 (2000). 
the plaintiff was unqualified, then evidence the plaintiff presented to prove the "qualifications" element is also relevant in assessing the employer's reason. Similarly, if an employer's stated reason for firing a plaintiff is incompetence; then evidence introduced regarding the "adequacy of performance" element is relevant to that reason. ${ }^{223}$ Also, if the employer's stated reason for terminating a plaintiff is to cut staff, then the plaintiff's proof that she satisfied the "replaced by another" element can also rebut the employer's reason. "Qualifications" or "level of performance" evidence may be pertinent even if it does not directly counter the employer's stated reason for its action. For example, in Laxton, the Fifth Circuit relied on evidence of both the plaintiff's qualifications and level of performance to find that a jury could reasonably question the truth of the employer's claim that it fired the plaintiff for minor violations of policy. ${ }^{224}$

In such situations, evidence the plaintiff initially introduced to prove her prima facie case is reevaluated at the summary judgment phase because the evidence itself has probative value regarding the employer's motivation for the action at issue. Such evidence often indicates the falsity of the employer's proferred reason for its action, which the Supreme Court in Reeves and elsewhere has recognized as "persuasive" evidence of a discriminatory motive. ${ }^{225}$ In other cases, the evidence is probative because it suggests the

223. See Malamud, supra note 3, at 2285-87. Professor Malamud has even argued that because the evidence regarding the plaintiff's qualifications or competency and the evidence regarding the employer's reason is so often the same, the distinction between the McDonnell Douglas stages frequently breaks down. See id.

224. Laxton v. Gap, Inc., 333 F.3d 572, 582-83 (5th Cir. 2003). The Laxton plaintiff presented evidence that she had a successful career in retail at other stores before the Gap lured her away with a $\$ 1,000$ raise. Proof that her store's revenues exceeded quotas, she worked more than 70 hours a week, and the Gap rewarded her with monthly bonuses evidenced the plaintiff's high level of performance.

225. See Reeves v. Sanderson Plumbing Prods., Inc., 530 U.S. 133, 147-48 (2000). In Reeves, the Supreme Court stated:

Proof that the defendant's explanation is unworthy of credence is simply one form of circumstantial evidence that is probative of intentional discrimination, and it may be quite persuasive. See St. Mary's Honor Center v. Hicks, 509 U.S. 502, 517 (1993)] ("Proving the employer's reason false becomes part of (and often considerably assists) the greater enterprise of proving that the real reason was intentional discrimination"). In appropriate circumstances, the trier of fact can reasonably infer from the falsity of the explanation that the employer is dissembling to cover up a discriminatory purpose. Such an inference is consistent with the general principle of evidence law that the factfinder is entitled to consider a party's dishonesty about a material fact as "affirmative evidence of guilt." Wright v. West, 505 U.S. 277, 296, 120 L. Ed. 2d 225, 112 S. Ct. 2482 (1992); see also Wilson v. United States, 162 U.S. 613, 620-621, 40 L. Ed. 1090, 16 S. Ct. 895 (1896); 2 J. Wigmore, Evidence $\S 278(2)$, p. 133 (J. Chadboum rev. ed. 1979). Moreover, once the employer's justification has been eliminated, discrimination may well be the most likely alternative explanation, especially since the employer is in the best position to put forth the actual reason for its decision. Cf. Furnco Constr. Corp. v. Waters, 438 U.S. 567, 577, 57 L. Ed. 2d 957, 98 S. Ct. 2943 (1978) ("When all legitimate reasons for rejecting an applicant have been eliminated as possible reasons for the employer's actions, it is more likely than not the employer, who we generally assume acts with some reason, based his decision on an impermissible consideration"). 
employer had an improper motive for its action. In either situation, the evidence's probative value stands or falls on its own, without reference to the arbitrary construct of a "strong" or "weak" prima facie case. By contrast, the fact that the "prima facie case" as a whole is strong or weak has little or no probative value regarding the employer's motivation. For example, a prima facie case may be designated as "weak" because the plaintiff fails to present evaluations or other proof of "adequate performance." This designation, however, does not elucidate the employer's motivation if the employer claims it discharged the plaintiff as part of a staff reduction conducted in seniority order.

In sum, after the employer has produced evidence of a reason, a court should draw a distinction between the "prima facie case" as a whole and the evidence that the plaintiff presented to support it. The prima facie case as a whole is no longer relevant, while some of the supporting evidence may be. This approach complies with Aikens because the evidence is being considered for proper reasons. Rather than considering the evidence because it proves a now irrelevant prima facie case, courts should consider prima facie evidence because it has probative value regarding issues still extant in the case-the credibility of the employer's stated reason and the employer's true motivation for its action. ${ }^{226}$

Reeves should be construed in a way that is consistent with this approach, and therefore consistent with Aikens. Consequently, the term "prima facie case" in the Reeves list of factors should not be interpreted to mean the prima facie case as a whole, i.e., the standard elements of a prima facie case under McDonnell Douglas and its progeny. ${ }^{227}$ Instead, "prima facie case" as a Reeves factor should be understood to refer to the plaintiff's underlying evidence in support of the prima facie case. In fact, this first Reeves factor should be interpreted to mean all the evidence presented by the plaintiff, other than the evidence that the employer's reason is false, which is captured by the second Reeves factor. ${ }^{228}$ The first factor would then properly balance the third and final factor on the Reeves list, which is "any other evidence that supports the employer's case". ${ }^{229}$ This Reeves construction would clarify the task of a court

Reeves, 530 U.S. at $147-48$.

226. This approach also addresses a concern raised by Professor Michael Zimmer, that some courts (e.g., the Fifth Circuit) have erroneously concluded that "the evidence establishing the plaintiff's prima facie case loses all its probative force once the defendant introduces its rebuttal evidence," and that this conclusion unduly weakens the plaintiff's case. Zimmer, Leading, supra note 171 , at 179 (emphasis added). The better approach is to allow courts to consider evidence supporting the prima facie case but not the "prima facie case" and its elements. See supra notes 221-225 and accompanying text.

227. See supra Part III.A (discussing cases applying typical "list of elements" definition of prima facie case).

228. See Reeves, 530 U.S. at 149 (listing second factor as "the probative value of the proof that the employer's explanation is false").

229. Id. 
deciding a discrimination case on summary judgment: to consider all the evidence presented by the plaintiff and defendant, and assess its probative value on the central question of the employer's motivation.

\section{CONCLUSION}

What is the role of the prima facie case stage of the McDonnell Douglas analysis? The Supreme Court has stated that the prima facie case "eliminates the most common nondiscriminatory reasons for the [employer's action]. ${ }^{230}$ Professor Michael Zimmer has described the prima facie case as the first step in "a process of elimination in which circumstantial evidence is used progressively to eliminate possible actions for the employer's actions other than discrimination."231 Echoing the Supreme Court, Professor Zimmer has said, " $[t]$ he evidence of the prima facie case operates to negate the inference that any of the most common, nondiscriminatory reasons explains defendant's action." 232

Courts have also stated that the prima facie case functions to force the employer to produce a reason for its action, rather than merely denying discriminatory motive and saying nothing about its true motive. The Eleventh Circuit has explained, "[t]o assist him in this endeavor [of proving discrimination], the plaintiff may, if he chooses, attempt to establish the McDonnell Douglas presumption and thereby force the defendant to articulate a lawful reason for the adverse employment action."233 Similarly, the Second Circuit has stated that "the McDonnell Douglas presumption . . . is designed to force employers to come forward with reasons ....234 Scholars have also recognized that the prima facie case, and the mandatory presumption it creates, is intended to compel the employer to come forward with a reason for its action. $^{235}$

Consequently, once the employer produces its reasons for its challenged action, the "prima facie case" serves no viable purpose in the case. The second purpose, of pushing the employer to produce its reason, has been accomplished. The first purpose, of negating possible nondiscriminatory reasons, is immaterial once the employer asserts actual reasons for its decision. It is worth recalling

230. Tex. Dep't of Cmty. Affairs v. Burdine, 450 U.S. 248, 253 (1981).

231. Zimmer, Leading, supra note 171 , at 177.

232. Id. at 181 .

233. Wright v. Southland Corp., 187 F.3d 1287, 1292 (11th Cir. 1999).

234. James v. N.Y. Racing Ass'n, 233 F.3d 149, 154 (2d Cir. 2000).

235. See Chambers, Discrimination, supra note 172, at 559 ("That the presumption of discrimination is fully negated with the mere articulation of a reason for the job action suggests that the presumption was meant as a strong incentive for the employer to present a case rather than as a reflection of a belief that the prima facie case actually proves discrimination."); Michael Zimmer, Chaos or Coherence: Individual Disparate Treatment Discrimination and the ADEA, 51 MERCER L. REV. 693, 706 (2000) (explaining that McDonnell Douglas "creat[es] a rebuttable presumption of liability to force the employer to come forward with the nondiscriminatory reason it claims justified its decision."). 
that the possible "reasons" covered by the elements of the prima facie case are not based on evidence in an instant case or any particular case. They were established by the Supreme Court and other courts in the abstraci, based on the courts' speculation about what are likely to be the most common reasons that employers fire employees, or reject them for hiring or promotion. Once the employer identifies reasons as the ones that actually motivated it, there is no need for "speculative" reasons. They need not be negated; they can and should be cast aside.

It is also worth recalling that at the prima facie stage, the "possible" reasons are not proved by the employer, but are to be disproved by the plaintiff. The plaintiff carries the burden to prove that she applied, met the required qualifications, or performed adequately. Thus, "weakness" in the prima facie case always refers to the absence of evidence, not to the presence of evidence that one of the "prima facie reasons" actually motivated the employer. A factfinder must base her determination that a nondiscriminatory reason motivated the employer on evidence present in the record. It would be unreasonable to base the finding of motive on the absence of evidence, and so it would be unreasonable to base it on "weakness" in the prima facie case.

After the employer has produced the purported reasons for its decision, the reasons implicated by the prima facie case no longer relate to any real factual issues in the case. Of course, if any of the employer's proffered reasons coincide with a "prima facie case" reason, then that reason is relevant. It remains relevant because the employer has given it as a reason, not because it is an element of the prima facie case. By contrast, when an element of the prima facie case has not been identified by the employer as one of the true reasons for its action, then there is no basis for finding that element to have any connection with the employer's motivation.

In some cases, courts consider a prima facie element when deciding summary judgment or judgment as a matter of law although the prima facie element does not relate to any real factual issues in the case. In such circumstances, the prima facie case operates as an artificial obstacle the plaintiff must overcome. For example, a court can dismiss the plaintiff's case for "weak" qualifications, even when the employer never claimed insufficient qualifications as the reason for its decision. Each of the prima facie elements then imposes an arbitrary condition the plaintiff must satisfy, even when no one claims the element had anything to do with the employer's motive. This is tantamount to requiring, in a personal injury case, the plaintiff to prove that she has a good driving record, even if no one alleges she caused the accident. In an even more apt analogy, this is comparable to allowing a court adjudicating a personal injury case to weigh the plaintiff's poor academic record compiled years before the accident. 
The McDonnell Douglas analysis, particularly the "prima facie case" in the first stage, has come in for much recent criticism. ${ }^{236}$ There is currently a debate among many scholars over whether the McDonnell Douglas analysis should be abandoned and replaced. I hope to, in the future, join in that debate myself. Right now, that scholarly debate is ahead of the facts on the ground. Courts around the country are still using the McDonnell Douglas analysis to decide hundreds of discrimination cases every month. ${ }^{237}$ McDonnell Douglas will continue to be used in discrimination litigation for at least the next several years, despite all its flaws. Therefore, it is imperative that courts not compound the flaws of the McDonnell Douglas analysis by giving its most-criticized component, the prima facie case, undue weight in the final stage of the analysis.

The prima facie case was designed to perform its functions in the first stage of the analysis: to screen out hypothetical nondiscriminatory reasons why the plaintiff suffered adverse employment action, and to pressure the employer to assert its reasons for that action. The work of the prima facie case is complete when an employment discrimination case reaches the second stage of the McDonnell Douglas analysis, a reality that the Supreme Court recognized in Aikens. Ignoring that vital lesson and allowing the prima facie case to pop up again will cause innumerable problems and wreak injustice in case after case.

236. See supra note 3 (citing commentators who have criticized first stage of McDonnell Douglas framework).

237. In a LEXIS search on January 17,2006 , the author found more than 1,700 cases that had applied the McDonnell Douglas analysis to a discrimination case in 2005 and early 2006. 


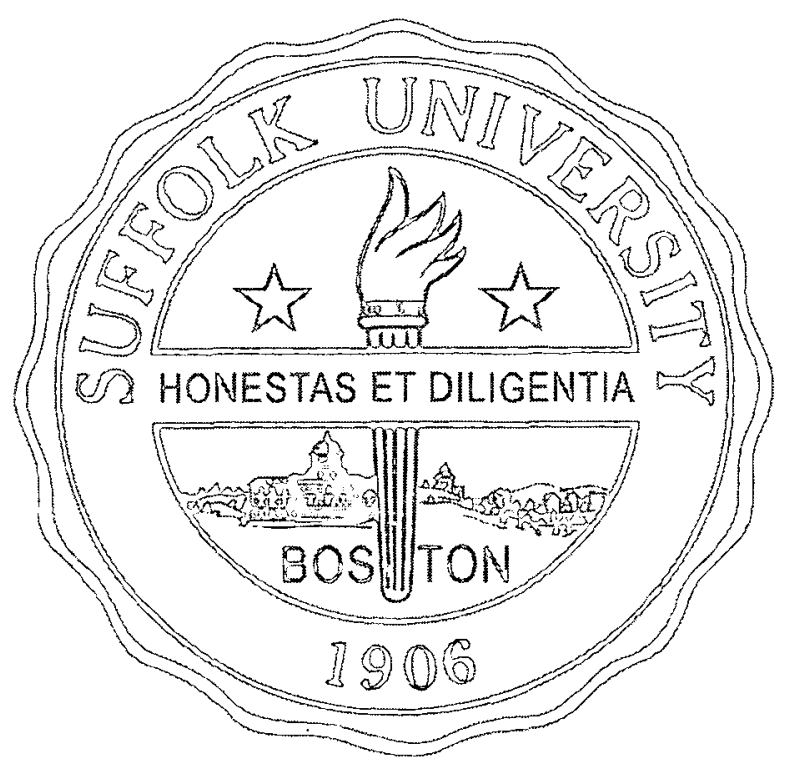

